\title{
Kentsel Ulaşım, Salgınlar ve Covid-19: Ankara Toplu Taşıma Sistemi ${ }^{1}$
}

\author{
Hind Shahin ${ }^{2}$ \\ ORCID: 0000-0003-4524-1986
}

\author{
Emine Yetişkul ${ }^{3}$ \\ ORCID: 0000-0003-0829-1562
}

\section{Öz}

Bu çalışmada, yolculuklar ile salgın hastalıklar arasındaki pozitif ilişki, kentsel ulaşım özelinde incelenmektedir. Türkiye'de ilk vakanın görüldü̈̆̈̈̈ 11 Mart 2020 tarihinden itibaren Covid-19 Pandemisi sürecinin bir yıllık dönemi Ankara toplu taşıma sistemine odaklanılarak değerlendirilmektedir. Toplu taşımanın kalabalık ortamları, kısa döngülerle işletilen araçları ve sık ziyaret edilen yapıları, bulaşıcı hastalıkların yayılımını tetikliyor gibi görünse de süreç içinde toplu taşıma ortamlarında Covid-19 hastalı̆̆ına yakalanma riskinin çok yüksek olmadı̆̆ı görülmüştür. Aslında, toplu taşımada bulaşı etkileyen faktörler göz önüne alınarak uygulanan idari ve teknik önlemlerle beraber kişisel korunma hastalı̆̆ın yayılımını kontrol etmemizi să̆lamaktadır. Bu çerçevede çalışmamızda hastalıkların yayılmasını etkileyen faktörler kısaca açıklandıktan sonra toplu taşıma sistemlerinde uygulanan bulaşı kontrol edici ve çalışanlar ile yolcuları koruyucu önlemler uluslararası örneklerle tartışlmaktadır. Ankara özelinde ise toplu taşıma sisteminin genel özellikleri ile pandemi öncesi dönemin kullanım yoğunluğu verildikten sonra alınan idari kararlarla uygulanan teknik önlemler aktarılmaktadır. Kentlerdeki hareketliği durdurmanın ve halk sağglığı açısından sıfır risk ortamları yaratmanın mümkün olamayacă̆ının kabulü ile toplu taşıma sistemlerini salgın döneminde olduğu kadar sonrası normalleşme veya iyileşme döneminde de yönetmek zorundayız. Bu süreçlerin iyi yönetilememesi toplu taşımanın özel ulaşım karşısında gerilemesine neden olacaktır ki çevre kirliliği başta olmak üzere ekonomik ve sosyal kayıpları artırarak sürdürülebilirlĭ̆i tehdit edecektir.

Anahtar Kelimeler: Hareketlilik, Ankara toplu taşıma, Salgınlar, Covid-19 önlemleri

\footnotetext{
${ }^{1}$ Bu makale Hind Shahin tarafından 2021 yılında ODTÜ, Kentsel Politika Planlaması ve Yerel Yönetimler Programinda tamamlanan 'Evaluation of Covid-19 Pandemic Measures for Mass Transportation in Ankara' başlıklı yüksek lisans tez çalışmasından üretilmiştir.

${ }^{2}$ M.SSc., Orta Doğu Teknik Üniversitesi, E-mail: hnd.shaheen@gmail.com

${ }^{3}$ Prof. Dr., Orta Doğu Teknik Üniversitesi, E-mail: yetiskul@metu.edu.tr

idealkent @ Kent Araştırmaları Dergisi (Journal of Urban Studies)

http://idealkentdergisi.com
}

Geliş Tarihi Received Date: 13.02.2021 Kabul Tarihi Accepted Date: 27.08.2021 


\title{
Urban Transport, Pandemics and Covid-19: Ankara Public Transit System
}

\author{
Hind Shahin 4 \\ ORCID: 0000-0003-4524-1986
}

\author{
Emine Yetişkul 5 \\ ORCID: 0000-0003-0829-1562
}

\begin{abstract}
In this study, positive relationships between pandemics and trips are investigated in the context of urban transportation. One-year time interval of Covid-19 Pandemic from March 11, 2020 when the first case was detected in Turkey is evaluated by focusing on Ankara public transportation system. Even crowded areas, vehicles operated in short turnovers and frequently visited structures of public transportation might seem to trigger spread of the pandemic, it is seen that risk of getting the Covid-19 disease is no higher in public transportation. In fact, administrative and technical precautions taken considering factors affecting spread in the public transportation combined with personal protection help control disease spread. In this line, after briefly explaining factors affecting disease spread, we discuss measures for controlling spread and protecting passengers and employees with international examples. In the particular case of Ankara, after giving general characteristics and figures of public transportation system prior to pandemic outbreak, administrative measures affecting public transportation usage and technical precautions are given. Assuming impossibility of halting urban mobility and creating zero-risk areas in terms of public health, as managed during pandemic period, public transport systems needs to be managed during normalization or recovering periods afterwards.
\end{abstract}

Keywords: Mobility, Ankara public transit, Pandemics, Covid-19 precautions

\footnotetext{
${ }^{4}$ M.SSc., Middle East Technical University, E-mail: hnd.shaheen@gmail.com

${ }^{5}$ Prof. Dr., Middle East Technical University, E-mail: yetiskul@metu.edu.tr

idealkent @ Kent Araştırmaları Dergisi (Journal of Urban Studies) 


\section{Giriş}

2020 yılının başından bu yana, dünya hızla yayılan şiddetli Akut Solunum Sendromu Koronavirüs-2'nin (SARS-CoV-2) neden olduğu Covid-19 bulaşıc1 hastalığıyla karşı karşıya kalmıştır. İlk vaka, 2019 yılının Aralık ayında Çin'in Wuhan kentinde tespit edilmiştir. Dünya Sağlık Örgütü (DSÖ) hastalığa ilişkin 30 Ocak 2020'de 'Uluslararası Önem Arz Eden Halk Sağlığı Acil Durumu' ilan etmiştir. Türkiye'de ise pandeminin ilanı, ilk vakanın görüldüğü 11 Mart 2020 tarihinde gerçekleşmiştir (WHO, 2021). O zamandan bu yana hastalık dünyada ve Türkiye'de huzla yayılmaya devam etmektedir. 1990'lardan bu yana özellikle bulaşıcı olmayan kronik hastalıkların oluşturduğu çevrelere odaklanan halk sağlığı ve ulaşım sistemlerindeki terörist saldırılara odaklanan ulusal güvenlik, Covid-19 salgınına hazırlıksız yakalanmıştır. Çünkü bulaşıcı hastalıkların 'geçmişte kaldığı' düşünülmekteydi. Birinci Dünya Savaşı'nın sonundaki İspanyol gribinden bu yana 100 yıldır kontrol edemediğimiz bir hastalığın herkesi ve her yeri etkileyebileceği hiç düşünülmemişti (Batty, 2020). Bulaşıcı hastalıklara karşı geliştirilen bu sahte güvenlik duygusu, 1960'larda elde edilen bir dizi başarıdan kaynaklanmaktaydı. Çocuk felci, çicek hastalığı gibi hastalıklar hızla ortadan kalkmış ve halk sağlığı sorunu olmaktan çıkmıştı. Dönem dönem kimi bulaşıcı hastalıklar (yeni bölgelerde veya hastalıktan daha önce etkilenmiş bölgelerde) yeniden ortaya çıksa da dünya çapında bir pandemiye dönüşmeden kontrol altına alınmıştı. Yine de görece bu kısa süreli SARS, MERS ve Ebola gibi epidemik salgınlar, bize bulaşıcı hastalıkların yayılma hızı yanı sıra halk sağ lığı açısından ne tür durumlar ortaya çıkarabileceğinin ipuçlarını sunmaktaydı.

\section{Yolculuklar ve Salginlar}

Bulaşıcı hastalıkların ortaya çıkması veya kaybolan bir bulaşıı hastalığın yeniden yaygınlaşması birçok faktör veya olayın aynı anda bir araya gelmesine veya sırasıyla oluşmasına bağlıdır (Wilson, 1995). Bu ortaya çıkış veya yeniden yaygınlaşma, çok karmaşık süreçler içermekteyse de sürece katkıda bulanan faktörleri, genel olarak çevresel değişiklikler ile insanların demografik yapısındaki veya davranışlarındaki değişiklikler olmak üzere iki ana grupta toplayabiliriz. Birinci gruptaki değişiklikler mikrobiyal adaptasyonla ilgiliyken (Lederberg, Shope ve Oaks, 1992; Wilson, Levins ve Spielman, 1994), ikinci gruptaki değişiklikler ise ekonomik ve teknolojik gelişmeler, mal ve hizmet sunumunun genişlemesi, ticaretin artması ve halk sağlığı önlemlerinde bozulmayla ilişkilidir. Yolculuklar ise hem bulaşıcı hastalığın ortaya 
çıkmasına hem de özellikle hastalığın yayılmasına katkıda bulunduğu için belki de ikinci grubun en çok tartışlan örneğidir. Kaydedilen tarih boyunca ve öncesinde insanlar, bir yerden başka bir yere, sürekli farklı amaçlarla hareket etmiş ve göçmüştür. Bu hareketlilik, başlangıçta avcı/taşıyıcı toplumların doğası gereği ortaya çıksa da zamanla yolculukların amaçları değişmiştir. Tarımsal ürünleri veya yiyeceği toplamadan modern zamanlardaki iş, okul, alışveriş ve eğlenceye kadar amaçlar çeşitlenmiş; en sonunda yolculuğun kendisi de rekreatif olarak bir amaca dönüşmüştür (Mokhtarian ve Salomon, 1999). Farklı nedenlerle olsa da insanlar sürekli değişen ve hızlanan ulaşım modlarını kullanarak mesafeler kat etmişlerdir. Hareketlilikte gelinen bu noktayı, Jonathan H. Cossar' in 'insanın yolculuk serüveninin ve ardından gelen sonuçlarının göstergesi' (1994, s. 36) olarak özetlemesi, aslında Covid-19 hastalığının da nasıl bu derece hızla dünyaya yayıldığı sorusunu da cevaplamaktadır.

William McNeill 1979 yılında yayınlanan 'Salgınlar ve Halklar' başlıklı kitabında, bulaşıcı hastalıkların dünya tarihini şekillendirmede, savaş ve barıştaki güç dengelerini değiştirmeden toplumlarının yapısını ve yaşadığı coğrafyayı belirlemeye kadar çok önemli rol oynadığını ayrıntılarıyla anlatmaktadır. ${ }^{6}$ McNeill eserinde, ticaret kervanları ile haclara ek olarak, askeri operasyonların da insanlık tarihindeki en şiddetli hastalık salgınlarını körüklediğini belirtmiştir. Çiçek hastalığı ve veba salgınları bunun örnekleridir. Donald Hopkins, 'Prensler ve Köylüler: Tarihte Çiçek Hastalığı' adlı kitabında, ilk olarak oldukça erken bir tarih olan MÖ 1000'li yıllarda insanlarda görüldüğü bilinen çiçek hastalığının Mısır'dan Hindistan'a yayılmasının izini sürmüştür (Hopkins, 1983). MS 542 ile 750 yılları arasındaki dönemde görülen Jüstinyen Vebası, Akdeniz ülkelerinde Pers ve Roma ordularını ve nüfuslarını tahrip ederek yayılmıştır. Orta Doğu'da ticaret yolları boyunca yayılan bu hastalığın, 7. YY'da Müslüman orduların fetihlerine de katkı sağladığını göstermektedir (Cossar, 1994). Bulaşıcı hastalık salgınlarının en vahim örneklerinden birisi, Moğolistan ve komşu bölgelerinde MS 1320 yılında başlayan Kara Ölüm Salgını'dır. Hastalık 30 yıl boyunca Çin, Hindistan, Asya, Orta Doğu, Kuzey Afrika, Rusya ve Avrupa'da Moğol İmparatorluğu'nun ticaret yolları boyunca aralıksız yayılmıştır. 15. YY'ın sonlarında bulaşıcı hastalıkların yaygın olduğu Avrupa'dan sömürgecilerle Amerika kıtasına getirilen çiçek hastalığ1 ve kızamık, 1517 yılından başlayarak 1530 yılına kadar yaklaşık iki milyon yerlinin yok olmasına sebep olmuştur (Cossar, 1994).

\footnotetext{
${ }^{6}$ Eserin Türkçe adı, Çıpa, H. Erdem tarafından 1995 yılında Toplumsal Tarih Dergisi'nin 22(4) sayısında yayınlanan 'McNeill' in “Salgınlar ve Halklar" 1 Üzerine Düşünceler' yazısı esas alınarak belirlenmiştir.
} 
Yakın döneme gelirsek koronavirüsler, son 20 yılda iki ciddi hastalığa daha yol açmıştır (Pan ve diğerleri, 2020). Bunlardan birincisi, ilk olarak Kasım 2002'de Çin'in Guangdong Eyaletinde tespit edilen “Şiddetli Akut Solunum Sendromu" olan SARS'tır (Ahmad, Krumkamp ve Reintjes, 2009). Sağlik personeli arasında hızla yayılmıştır. Bulaşlı doktorlardan birisinin Şubat 2003'de havayolu ile Hong Kong'a gitmesi ve otelde konaklaması, hastalığın küresel ölçekte yayılmasına yol açmıştır (Tsang ve diğerleri, 2003). SARS hastalığının bulaşması Temmuz 2003'de başarıyla durdurulmuş olsa da bu yarasa kaynaklı virüsün küresel yayılımı, 32 farklı ülkede 8.447 vakaya ve 774 ölüme neden olmuştur (WHO, 2003). Koronavirüs ailesinin farklı bir üyesinin neden olduğu ikinci bulaşıcı hastalık salgını ise 2012 yılında ortaya çıkan ve 'Orta Doğu Solunum Sendromu' olarak adlandırılan MERS'tir; salgın, Suudi Arabistan' da başlamış ABD, İngiltere, Fransa ve Güney Kore dahil pek çok farklı ülkeye yayılmıştır (Pan ve diğerleri). Araştırmalarla MERS virüsünün de yarasa kaynaklı olduğu gösterilse de insanlara, ara taşıyıcı olan develerden bulaştığ1 tespit edilmiştir (Al Hajjar, Memish ve McIntosh, 2013; Omrani, AlTawfiq ve Memish, 2015). Dünya genelinde 27 ülkede Kasım 2019 itibariyle toplam 2.494 kişiye bulaşmış ve 858 kişinin vefatına sebep olmuştur (WHO, 2019). Bugün ise dünya, önceki koronavirüslerden çok daha bulaşıcı olan Covid-19 ile karşı karşıya kalmıştır.7

Kısaca yukarıda örneklerle açıklamaya çalıştığımız gibi hareketlilik ile bulaşıcı hastalıklar arasında yerleşik bir ilişki vardır. İnsanlar, seyahat ederken farklı genetik havuzların benzeri görülmemiş oranlarda ve kombinasyonlarda karışmasına izin veren mikroplar, hayvanlar ve sayısız biyolojik canlı ile seyahat etmektedir. Bu durum, bulaşıcı hastalıkların taşınımı ve dolaşımı için en iyi ortamı sunmaktadır. Hareketlilik çoğunlukla günlük kısa mesafeli döngüleri içerse de bulaşı ı hastalıkların yayılımında uluslararası havayolu yolculukları araştırmalar da öne çıkmıştır (Örnekler için bknz. Mangili ve Gendreau, 2005). Ulaşımın farklı modlarında da solunum yolu bulaşı çalışılmiştır (Örneğin; Joseph, Ricketts, Yadav ve Patel, 2009; Ward ve diğerleri, 2010). Toplu taşımanın ortamı, araçları ve yapıları diğer ulaşım sistemleriyle benzer özellikler göstermesine rağmen konuyla ilgili çalışmalar görece az

\footnotetext{
7 İlk vaka 2019 yılında görüldüğü için hastalık Covid-19 olarak adlandırılmıştır. 31 Ağustos 2021 tarihi itibariyle dünyada vaka sayısı 219 milyona Türkiye'de ise 6,4 milyona yaklaşmıştır. Kayıp sayısı da sırasıyla yaklaşık 4,5 milyon ile 56,5 bini aşmıştır (Worldometer, 2021).
} 
araştırma ile sınırlı kalmıştır. Troko vd. (2011) otobüs ve tramvay kullanımının kış aylarında solunum yolu hastalığı kapma riskini artırdığını bulmuştur. Çeşitli araştırmalar hava aracılığıyla bulaşan hastalıklar ile toplu taşıma kullanımı arasında bağlantı olduğunu doğrulamıştır (Browne, Ahmad, Beck ve Nguyen-Van-Tam, 2016; Feske, Teeter, Musser ve Graviss, 2011). Bulaş riskini ölçmek için sayısal modellemeler de yapılmıştır. Örneğin, Zhao ve diğerleri (2015), Pekin metro sisteminde salgın riskini yolcu hareketlilik verileriyle araştırmıştır. Londra'da yapılan farklı bir çalışmada yeraltı raylı sistem kullanımı ile grip benzeri hastalık (influenza-like illness) vakaları arasındaki ilişki incelenmiş, yeraltında daha uzun veya daha fazla teması içeren yolculukların yapıldığı bölgelerde vaka sayılarının da yükseldiği sonucuna ulaşılmıştır (Goscé ve Johansson, 2018). Ancak bu araştırmalar, bulaşıcı hastalıkları toplu taşımanın kaderi yapmaz.

\section{Toplu Taşıma Sistemlerinde Bulaşı Etkileyen Faktörler}

Ulaşım sistemleri dahil yapılı çevrede hava aracılığıyla yayılan hastalıkların bulaşması, patojenlerin iletimi ve yayılması, hastalar, taşıyıcılar, ortamın kullanıcıları ve fiziksel çevre arasındaki bir dizi ardışık etkileşime bağlıdır (Faass, Greenberg ve Lowrie, 2013). Bu konudaki mevcut literatür, biyolojik tehlikelere maruz kalma riskini etkileyen faktörler hakkında bize temel bilgiler sunmaktadır. Bu faktörler aşağıda patojen iletiminin, toplu taşıma sisteminin ve yolcu hareketliliğinin özellikleri başlıkları altında incelenmektedir. Ancak gruplamanın net ayrımlarla yapılamayacağı da not edilmelidir. Zira bulaş, katedilen mesafe, örneğin, hem sisteminin tasarımına ve işletimine hem de kişisel yer seçim tercihlerine de bağlıdır.

\section{Patojen İletim Yollar}

Hastalığa neden olan mikroorganizmanın yapısına bağlı olarak bulaşma yolları, doğrudan temas, dolaylı temas, damlacık teması veya havadan iletim olarak farklılaşmaktadır. Doğrudan iletim, hastalıktan sorumlu mikroorganizmanın fiziksel temas ile aktarımıdır. Giderek kalabalıklaşan toplu taşıma ortamlarında artan temas, hastalığın bulaşma olasılığını da artırmaktadır. Dolaylı iletim ise mikroorganizmanın türüne, yüzeyin malzemesine ve yüzeyin temizlenme ile ilaçlanma sıklığına bağlı olsa da, kontamine bir yüzeyle temas edildiğinde hastalığın bulaşmasını ifade etmektedir (Siegel ve diğerleri, 2007). Damlacık aracılığıyla hastalığın bulaşması ise bulaşlı kişi öksürdügünde, hapşırdığında veya konuştuğunda üretilen damlacıkların diğer kişi- 
nin gözleri, burnu veya ağzı ile temas ettiğinde gerçekleşir. Damlacıklar havada uzun süre kalamamakta ve sonunda çökmektedir. Ancak bazı damlacık kalıntıları veya mikroorganizma yüklü toz parçacıkları uzun süre havada asılı kalabilmektedir. Bu damlacığın büyüklüğüne ve bileşimine göre değişse de genellikle küçük damlacıklar, havada daha uzun süre asılı kalarak hava akımları ile ilk kaynağından uzağa taşınabilirken, büyük damlacıklar da yüzeylere kolay yerleşmektedir. Böylelikle damlacıklarla yayılan patojenler, bilet ve para makineleri, araç içi koltukları, bekleme oturakları, kapı kolları, asansör düğmeleri, korkuluklar ve küpeşteler gibi farklı yüzeylere birikerek dolaylı temas ile hastalığının iletiminde yeni bir döngü başlatırlar. Yukarıda açıklanan iletim türleri birbirini dışlamaz. Aslında kaynağından aktarım, farklı iletim yollarının çeşitli birleşimlerini içeren çok yönlü bir süreç olduğu için tek bir yolu saptamayı ve diğerlerini hariç tutmayı zorlaştırmaktadır.

\section{Toplu Taşıma Sisteminin Özellikleri}

Patojenin iletim özelliklerin yanı sıra diğer risk değişkeni ulaşım sistemiyle ilgilidir. Entegre bir toplu taşıma, otomobile kıyasla tüketilen enerji miktarını ciddi oranda azaltarak yolcu kilometre başına çevresel ayak izini düşürmektedir (Shapiro, Hassett ve Arnold, 2002). Buna ek olarak artan toplu taşıma yolcu sayısı, daha az trafik sıkışıklığına ve dolayısıyla yolculuk sürelerinin kısalmasına da neden olmaktadır. Bu çevresel üstünlük, çok sayıda yolcunun birbirine yakın bir şekilde seyahat etmesinden kaynaklanmaktadır ki ulaşım maliyetlerini de düşürerek toplumsal ve bireysel faydalara dönüşmektedir (Faass ve diğerleri, 2013). Ancak bulaşıcı hastalıklar ve salgın söz konusu olduğunda, bu toplumsal ve bireysel faydalar, kaygılara ve endişe verici konulara yerini bırakmaktadır. Üstelik toplu taşımanın kesintisiz ve döngüsel sunumu, halk sağlığıyla ilgili önlemleri almayı da zorlaştırmaktadır. Belirli sayıdaki çalışanın vardiyalı görev çizelgeleriyle araçları ve hizmet binalarını kısa sürede temizlemeleri ve ilaçlamaları pek de mümkün değildir (Faass ve diğerleri). Mutlak dakiklik ile işletilen sistemde bazen sosyal mesafe ilkesini uygulama oranı da düşmektedir. Bu nedenlerle, toplu taşımada belirli bir düzeye kadar hastalığın bulaşması ve yayılımı beklense de, bulaşı etkileyen faktörler daha çeşitlidir.

Yolcu trafiği özellikle zirve saatlerde hem aktarma noktalarında hem de araçlarda artar. Yolcu sayısı verilerinde kaydedilen en yoğun 10 raylı sistem hizmetinin \%47 ile \%66 arasında kapasitesinin üstünde işletildiği İngiltere'de, Ulaştırma Bakanlığı tarafından yürütülen bir araştırmada ortaya konulmuş- 
tur (DfT, 2011). Toplu taşımada kalabalığın, kapalı pencere ve kapılarla yetersiz havalandırmanın ve havalandırma sistemlerinin havadan iletimi artırarak hastalığın yayılmasını etkilediği Mohr ve diğerleri (2012) tarafından açıklanmıştır. Benzer bir şekilde Edelson ve Phypers (2011) vakaya yakınlığa ek olarak kapalı ve zayıf bir havalandırma sisteminin toplu taşıma araçlarında tüberküloza maruz kalma riskini artırdığını bulmuştur. Aslında, tüberküloz oranlarının yüksek olduğu ülkelerde yapılan çeşitli araştırmalarda toplu taşıma araçlarında kalabalığın ve yetersiz havalandırmanın hastalığın yayılmasına önemli ölçüde katkıda bulunduğu gösterilmiştir (Andrews, Morrow ve Wood, 2013; Horna-Campos ve diğerleri, 2010). Maruz kalma, kısa veya uzun bir yolculukta veya tekrarlanan yolculuklar sirasında meydana gelebilir. Yığılmalı maruz kalma olarak da adlandırılan, kısa fakat yinelenen maruz kalma süreleri de hastalığın bulaşında etkilidir (Horna-Campos ve diğerleri, 2007; Mohr ve diğerleri). Maruz kalma süresinin de etkisi patojen yoğunluğundan iletim yollarına veya sisteminin özelliklerine göre farklılaşsa da yoğun hatlardaki çok aktarmalı yolculukların riski yükselttiği açıktır. Son olarak, yapılı çevrenin hidrotermal durumunun da bulaşı etkilediği düşünülmektedir. 'Hidrotermal' terimi, 1sı ve nemin binalar boyunca hareketine atıfta bulunan birleşik bir kavramdır. Bina yüzeyinin tekrar tekrar ıslanması, kuruması, donması ve çözülmesi, yüzeylerde küf oluşumu gibi sorunlara neden olabilir. Ancak bu faktör yeterince araştırılmamıştır.

\section{Yolcu Hareketliliğ $i$}

Toplu taşıma sistemlerinde hastalığın yayılma sürecine etki eden bir diğer değişken ise yolcu davranışlarıdır. Hastalık yayma potansiyeli yüksek olan yolcu gruplarının ve yolcu hareketlilik biçimlerinin belirlenmesi, hastalığın bulaşmasını ve yayılmasını anlamamıza katkıda bulunur. Örneğin, olağan günlük ev-iş veya ev-okul yolculukları yapanlara göre gezginlerin hastalığın yayılmasında daha etkin oldukları kanıtlanmıştır (Pappalardo ve diğerleri, 2015). Günlük olağan yolculukların güzergahı bellidir ve bir kaç farklı konumu içerir. Gezginlerin yolculukları ise bir çok farklı yerleri içerdiği için tekrarlanan yolcu davranışları veya ziyaret edilen konumlar kolay belirlenemez. Covid-19 salgınının ortaya çıkması ve hızla pandemiye dönüşmesi, yolcu hareketliliğini anlamanın önemli olduğunu göstermiştir.

Shoghri, Liebig, Jurdak, Gardner ve Kanhere (2020) üç yolcu davranış boyutunun (gezginlik derecesi, katedilen mesafe ve yolculuk esnasında karşılaşma sayıları) hastalığın yayılımındaki etkilerini, Avusturalya, Sydney'de topla- 
nan akıllı kart verileriyle otobüs yolculukları temelinde incelemiştir. Çalışmada hastalık ulaşım ağına yayılarak simüle edilmiş, bulaş olasılığı ile patojenlerin havada asılı kalma süreleri değiştirilerek yolcu grupları arasında hastalığın yayılımı araştııılmıştır. En etkili hastalık yayıcılar, çok aktarmalı günlük olağan yolculuk yapanlar iken, patojenin havada tutunma süresi artırıldıkça çok aktarma yapan gezginler öne çıkmaktadır. Bulaş olasılığı artırıldıkça tüm gruplarda bir artıs gözlenirken, özellikle kısa mesafeli günlük olağan yolculuk yapanlar daha çok etkilenmektedir. Uzun mesafe kateden yolcular ile sık ziyaret edilen kalabalık yerlere uğrayan yolcuların daha kolay hastalığı yaydığı Shoghri, Liebig, Gardner, Jurdak ve Kanhere (2019) tarafından ortaya konulmuştur. Özetle, bulaşıcı hastalıkların yayılımı ile yolcu hareketlilik biçimleri arasında bağlantı olduğu kanıtlanmıştır. Patojen iletiminin, toplu taşıma sisteminin ve yolcu hareketliliğinin değişen özelliklerine göre salgınlara ilişkin farklı senaryolar kurgulamak ve bu doğrultuda korunma önlemlerine yönelik kısa ve uzun vadeli stratejiler ve politikalar geliştirmek mümkündür.

\section{Kontrol Edici ve Koruyucu Önlemler}

Bir önceki bölümde, hastalıkların bulaşmasını ve yayılmasını etkileyen faktörler genel olarak incelenmiştir. Her ne kadar faktörlerin etkileri, toplu taşmanın çok değişkenli ortamlarında net bir şekilde ölçülemese de bulaşmayı ve yayılmayı kontrol edici önlemleri geliştirmek mümkündür (Kowalski, 2012). Biyolojik tehditlere karşı kontrol önlemlerini doğru senaryo ile doğru yerde uygulamak gerekmektedir. Faass ve diğerleri(2013) yayılımı önlemeye yönelik stratejilerin çoğu okul ve hastane gibi yerlerde görece kolayca uygulanabilirken hareketliliğin ve geçişlerin yoğun olduğu ortamlarda (sosyal mesafe ilkesi gibi) uygulamanın zorlaştığın belirtmiştir. Bu nedenle toplu taşımaya özgü rehberlik yeknesak değildir. Örneğin, ulaşım sistemlerinde domuz gribine karşı alınan önlemler için özel eğitim düzenlenmesine ihtiyaç duyulmuştur (Faass ve diğerleri). Aslında, Covid-19 pandemisinin ortaya çıkması ve yayılmasındaki hız dikkate alındığında kentsel ulaşım sistemlerinin buna hazırlıksız olduğu açıcça görülmektedir. Üstelik farklı coğraflardaki ekonomik, sosyal, politik, teknolojik ve iklimsel koşullarında toplu taşıma hizmetlerinin sunumu birçok açıdan farklılaşmaktadır (Nasir, Campos, Christie ve Colbeck, 2016). Yine de araştırmalar ve uygulamalar yapılı çevrelerde hastalığın bulaşma zincirini kırmak için gerekli olan kontrol önlemlerini üç ana grupta tanımlamıştır. İdari ve teknik önlemlerin yanı sıra kişisel korunma da sağlıklı ulaşım için olmazsa olmazdır. 


\section{İdari Önlemler}

İdari önlemler, yönetimlerin ve işletmelerin kararlarıyla belirlenir. Genel olarak biyolojik tehlikelere maruz kalmayı azaltmak için hizmet usulleri ve politikası değiştirilmektedir. Belki de tüm idari önlemlerin ortak yönü, bir acil durum müdahalesi veya protokolünün olmasıdır. Bu protokoller, çalışanların programlarındaki ve görevlerindeki değişiklikleri, bazı hatların kapatılması, güzergahların yeniden belirlenmesi ve zaman çizelgelerinde değişiklikleri içerir. Buna ek olarak, işletmeler, hat, güzergah ve program değişiklikleri hakkında bilgi sağlayan, çalışanların ve yolcuların sorularını yanıtlayan ve şikayetleri işleme alan ve toplu taşımayı kullanırken nasıl güvende kalacağına dair anlaşılması kolay talimatlar hazırlayan acil durum iletişim kanalları geliştirmektedir. Bu iletişim kanalları güncel olmalı, akıllı telefon kullanıcısı veya sosyal medya kullanıcıları mobil uygulamalardan veya platformlardan yararlanmalıdır. Toplu taşıma araçlarının içinde bilgilendirici afişlerin kullanılması da bir başka paylaşım örneğidir. Ayrıca, idari önlemler çalışanlara pandeminin özellikleri, risk faktörleri ve korunucu davranışlar (Örneğin; öksürük görgü kuralları ve kişisel koruyucu ekipmanın bakımı) hakkında güncel eğitim ve öğretim sağlamayı da içermektedir. Bu tür eğitimler basit, anlaşılması kolay ve uygun dillerde mevcut olmalıdır. Hem yolcuların hem de çalışanların sosyal mesafe kurallarına uymaları, maske takmaları ve hijyeni sürdürmeleri istenmelidir.

\section{Teknik Önlemler}

Teknik önlemler, öncelikle çalışanların güvenliğini sağlamaya yöneliktir. Toplu taşımada örnek olarak, özellikle araç sürücülerini yolculardan ayıran fiziksel bariyerler yerleştirilmektedir. Bu tür bariyerler arasında paneller, şeffaf veya cam paravanlar, ayırıcı ağlar veya tehlike uyarı bandları yer almaktadır. Otobüs sürücülerini korumak ve sosyal mesafeyi sağlamak için arka kapıdan biniş, dünya çapında birçok işletme tarafından uygulanmaktadır. Diğer taraftan da çeşitli ödeme yöntemlerinin geliştirilmesiyle nakit para kullanımının caydırılması ve yüz yüze iletişimin azaltılması önlemler arasında yer almaktadır. Teknik kontroller ayrıca ortak kullanılan alanların, yapıların ve ekipmanların temizlenmesi ve dezenfektasyonunu da içermektedir. Özellikle yüzeylerin patojen deposu haline gelmesini önlemek için cam, deri, plastik ve çelik gibi farklı yüzeyler üzerinde çeşitli kaplama türleri test edilmiştir. Anti-mikrobiyal kaplamaların farklı hassas ortamlarda etkin olduğu kanitlanmıştır (Boyce, 2016; Casey ve diğerleri, 2010). Bu tür kaplamalar ulaşım sistemlerinde de görülmektedir. Örneğin, Şili'deki Valparaiso Metrosu'ndaki 
bir tren, anti-mikrobiyal bakır korkuluklar ve direklerle donatılmıştır (eHealth Network, 2013). Son araştırmalar, bakır yüzeylerde virüslerin 4 saatten uzun süre yaşamadığın iddia etmektedir. Hong Kong metrosunda da bazı yüzeyler nano-bazlı dezenfektanlar ile kaplanmıştır (Davies, 2007). Bununla birlikte, genel olarak ilaçlamanın ne sıklıkta (her yolculuğun sonunda, her gün veya her üç günde bir) uygulanacağı, en iyi uygulama yönteminin ne olduğu ve hangi tür dezenfektanın (anti-mikrobiyal koruma, UV ışığı, pestisit) kullanılacağı da tartışma konusudur.

Yaşanmakta olan Covid-19 pandemisinde New York, Metropolitan Ulaşım günde iki kere araçları ilaçlatırken, Singapur Metrosu ilaçlama işlemini üç kez uygulamaktadır. Boston metrosu ise yüzeyleri her 4 saatte bir ilaçlayacağını duyurmuştur. Diğer taraftan bir çok ülke bu işlemleri el emeği temelli yürütmekte iken Hong Kong, Raylı Toplu Taşıma düzenli yapılan temizliğe robot (buharlaştırılmış hidrojen peroksit robot) temizliğini de yakın zamanda eklemiştir. Şirket, robotun trenlerde elle ulaşılamayan küçük boşlukları temizlik için tasarlandığını belirtmiştir. Hangi dezenfektanın kullanılacağı konusunda da belirsizlikler vardır. Havaalanı Kooperatif Araştırma Programı (ACRP) 2013 Yılı Raporu'nda UV ışı̆̆ının kullanılmasını önermiştir (National Academies of Sciences, 2013). Çin, Ulusal Sağlık Komisyonu tarafından yayınlanan bir rehberin ardından Shangai'da bir toplu taşıma şirketi, otobüslerinin iç ve dışını UV ışıklarıyla dezenfekte etmektedir (Sustainable Bus, 2020). Şirket, işlemin otobüs başına 5 ila 7 dakika sürdüğünü ve virüslerin \%99,9'undan fazlasının öldürdüğünü iddia etmiştir. En önemlisi, havalandırmanın uygun şekilde çalıştırılarak bakımının düzenli yapılması ve yüksek verimli hava filtrelerinin takılması gerekmektedir. Bu tür önlemler genellikle etkilidir. Diğer idari önlemler ve kişisel korunmadan daha kalıcıdır. Ancak devamlılık önemli olduğu için uygulanması daha zordur.

\section{Kişisel Korunma}

Kişisel korunma ile Kişisel Koruyucu Ekipmanın (KKE) diğer önlemlere göre daha az etkili olduğu düşünülmesine rağmen (Nasir ve diğerleri, 2016), son salgın bunun çok önemli olduğunu kantlamıştır. Bunun esas nedeni KKE'ın uygulamaya geçirilmesindeki hızdır. KKE örnekleri arasında eldivenler, gözlükler, yüz siperleri, yüz maskeleri, önlükler, tulumlar, saç veya ayakkabı kılıfları, koruyucu giysiler ve solunum maskeleri (Örneğin, N95) sayılabilir. Salgın sırasında gerekli olan KKE türleri, genellikle çalışırken bulaşma riskine ve maruz kalınan görevlere göre farklılaşmaktadır. Özel KKE 
tavsiyeleri, mesleklere, coğrafi konuma, işçiler için güncellenmiş risk değerlendirmelerine ve belirli bir hastalığın yayılmasını önlemede KKE'nın etkinliğine ilişkin bilgilere bağlı olarak değişebilir. Genel olarak, sağlık çalışanları ve ilk müdahale ekipleri, KKE dağıtımı söz konusu olduğunda önceliklendirilir. Birçok kişi (Örneğin, otobüs şoförleri) yüksek enfeksiyon olasılığıyla karşı karşıya kalmasına ve özünde sağlığa erişimi sağlayan temel çalışanlar olmasına rağmen, ilk müdahale (yüksek risk) grubu dışında bırakılmaktadır. Aslında hastalığın yayılımını daha hızlı kontrol altına almak için yüksek risk grubu genişletilebilir. Buna ek olarak, işletmelerin çalışanlarına sadece ücretsiz KKE sağlaması değil KKE'ın doğru kullanımı ve kısıtları konusunda da eğitim vermesi gerekmektedir.

\section{Araştırmanın Yöntemi}

Yolculuklar ve salgınlar arasındaki yakın ilişkiyi konu edinen çalışmamızın birinci amac ilk vakanın görüldüğü 11 Mart 2021 tarihinden itibaren Covid19 Pandemisi sürecini deneyimleyen Türkiye'de Ankara'ya odaklanarak salgının 1 yıllık dönemini kentsel toplu taşıma sistemi üzerinden değerlendirmektir. Toplu taşımanın kalabalık ortamları, kısa döngülerle işletilen araçları ve sık ziyaret edilen yapıları, bulaşıcı hastalıkların yayılımını doğrudan etkiliyor gibi görünse de toplu taşımada bulaşı etkileyen faktörler göz önüne allnarak uygulanan önlemler hastalığın yayılımını kontrol etmemizi sağlamaktadır. Bu amaçla uluslararası yazından salgını etkileyen faktörler ve bulaşı önleyici tedbirler üç alt-başlık (idari ve teknik önlemler, kişisel korunma) altında yukarıda kısaca özetlenmiştir. Yolcu sayılarında ve dolayısıyla gelirlerinde sert düşüşler görülen Ankara toplu taşıma sistemi de pandemiden ciddi bir şekilde etkilenmiştir. Salgının seyrine ve vaka sayılarına göre Türkiye'de de sıkı tedbirler alınmıştır ve belirli dönemlerde esnetilse dahi uygulanmaya devam etmektedir. Aşağıda Ankara toplu taşıma özelinde pandeminin 1 yıllık süreci içinde uygulanan önlemler ve etkileri genel olarak aktarilacaktır.

Çalışmamızın ikinci amacı ise sadece kısa dönemde değil uzun dönemde de toplu taşıma sistemlerinde enfeksiyon bulaşma zincirinin kırılmasının halk sağlığı açısından önemini vurgulamaktır. Çünkü mevcut ve sürekli patojen tehdidini karşılayamayan bir sistem, kaçınılmaz olarak otomobil sahipliğini ve kullanımın tetikleyecektir. Bu da çevre kirliliği başta olmak üzere trafik sıkışıklığı ve kazaları da artırarak ekonomik kayıpları artıracak ve sürdürülebilirliği tehdit edecektir. Diğer bir taraftan da fiziksel hareketsizliğin veya hava kirliliğinin sebep olduğu farklı hastalıklara katkıda bulunacaktır. Riskin 
sıfır olamayacağı kabul edilirse ve doğru önlemler uygulanırsa toplu taşımanın şehirlerde dolaşım için güvenli bir yol olduğu görülecektir. Ampirik analizlerle de toplu taşıma ortamlarının diğer kamusal ve özel ortamlara kıyasla hastalığı yayma oranının daha yüksek olmadığı da kanıtlanmaya başlanmıştır. ${ }^{8}$ Kapsayıc1, adil, sürdürülebilir ve dirençli kentleşmeyi teşvik etmek, refahı desteklemek için uzun dönemli toplu taşıma odaklı çözümler geliştirmek ve politikalar oluşturmak zorundayız.

\section{Ankara Toplu Taşıma ve Covid-19 Önlemleri}

Covid-19 hastalığının yayılımını en aza indirmek amacıyla, Ankara toplu taşıma sisteminde halk sağlığı açısından riski yönetebilmek için çeşitli önlemler alınmıştır. Hem bu önlemleri değerlendirebilmek hem de pandemi öncesi ve sonrasını karşılaştırabilmek amacıyla öncelikle Ankara'nın kentsel ulaşım sistemine, modlarına ve yolculuk sayılarına ilişkin genel bilgiler aktaracağız. Ankara Büyükşehir Belediyesi toplu taşıma sistemi (kamu işletmecisi) Ankaray hafif raylı hattı, M1, M2, M3 ve M4 Metro hatları, teleferik hattı ve 5 otobüs bölgesinde 49 hareket noktasında Şubat 2020 itibariyle 335 hatta işletilen EGO otobüsleriyle hizmet vermektedir. TCDD tarafından işletilen Başkentray Banliyö hattı toplu taşıma ağının diğer bir kamu ulaşım modudur. Şehir içi özel toplu taşımada 2231 minibüs ve dolmuşa ek olarak 199 özel halk otobüsü (ÖHO) ile 160 özel toplu taşıma aracı (ÖTA) da işletilmekte ve ilçeler arasında 478 özel toplu taşıma aracı çalıştırılmaktadır. 'EGO Cepte' mobil uygulamasına göre EGO ve özel işletmecilere ait otobüsler, Ankara ilinde toplam 486 hatta hizmet vermektedir. Servis araçları ile taşınan yolcu sayıları dahil Şubat 2020'de günlük ortalama toplu taşıma yolcu sayısı 3.770.700'dir. Tablo 1 ve Şekil 1'de görüleceği gibi toplu taşımanın kentsel ulaşımdaki payı \%56,3 civarındadır. Özel otomobil ve taksi kullanımı ile yolcu sayıları 6.692.450'e ulaşmaktadır. ${ }^{9}$

\footnotetext{
${ }^{8}$ Örneğin, Fransız Sağlık Bilgileri Kamu Enstitüsü 9 Mayıs ve 28 Eylül 2020 tarihleri arasında toplanan verilerle Covid-19 vakalarının yalnızca \%1,2'sinin ulaşımla bağlantılı olduğunu göstermiştir. Çoğunlukla hastalığın işyerlerinde (\%24,9), okullarda ve üniversitelerde (\%19,5), sağlık merkezlerinde (\%11), kamusal veya özel alanlardaki çeşitli ortak etkinliklerde (\%11) ve aile toplantılarında (\%7) yayıldığını bulmuştur (UITP, 2020).

${ }^{9}$ Yolcu sayıları Ankara Büyükşehir Belediyesi, Ulaşım Dairesi Başkanlığı'ndan elde edilmiştir.
} 
Tablo 1. Şubat 2020 Ankara kentsel ulaşım günlük yolcu sayıları*

\begin{tabular}{lllll}
\hline Ulaşım Türleri & $\begin{array}{l}\text { Araç } \\
\text { Sayısı }\end{array}$ & $\begin{array}{l}\text { Yolcu } \\
\text { Sayısı }\end{array}$ & $\begin{array}{l}\text { Kentsel } \\
\text { Ulaşımdaki } \\
\text { Pay (\%) }\end{array}$ & $\begin{array}{l}\text { Toplu } \\
\text { Taşımadaki } \\
\text { pay (\%) }\end{array}$ \\
\hline EGO Otobüsleri & 1.540 & 769.400 & 11,5 & 20,4 \\
\hline Ankaray & 1 hat & 130.500 & 1,9 & 3,5 \\
\hline Metro & 4 hat & 358.500 & 5,4 & 9,5 \\
\hline Teleferik & 1 hat & 6.000 & 0,1 & 0,2 \\
\hline Başkentray Banliyö & 1 hat & 49.500 & 0,7 & 1,3 \\
\hline Minibüs-Dolmuş & 2.231 & 1.050 .000 & 15,7 & 27,8 \\
\hline Servis Araçları & 7339 & 830.000 & 12,4 & 22,0 \\
\hline Özel Halk Otobüsü (ÖHO) & 199 & 238.500 & 3,6 & 6,3 \\
\hline $\begin{array}{l}\text { Özel Toplu Taşıma } \\
\text { (ÖTA) }\end{array}$ & 160 & 123.400 & 1,8 & 3,3 \\
\hline İlçe Özel Toplu Taşıma Arac1 & 478 & 75.000 & 1,1 & 2,0 \\
\hline Özel Şirket Servis Araci & 1750 & 140.000 & 2,1 & 3,7 \\
\hline Toplu Taşıma Toplam & $\mathbf{1 3 . 6 9 7}$ & $\mathbf{3 . 7 7 0 . 7 0 0}$ & $\mathbf{5 6 , 3}$ & $\mathbf{1 0 0 , 0}$ \\
\hline Taksi & 7.701 & 340.000 & 5,1 & - \\
\hline Otomobil & 1.380 .614 & 2.581 .750 & 38,6 & - \\
\hline Özel Ulaşım & $\mathbf{1 . 3 8 8 . 3 1 5}$ & $\mathbf{2 . 9 2 1 . 7 5 0}$ & $\mathbf{4 3 , 7}$ & \\
\hline GENEL TOPLAM & & $\mathbf{6 . 6 9 2 . 4 5 0}$ & $\mathbf{1 0 0 , 0}$ & \\
\hline
\end{tabular}

*Tablo Ankara Büyükşehir Belediyesi, Ulaşım Dairesi Başkanlığı verileri ile hazırlanmıştır.

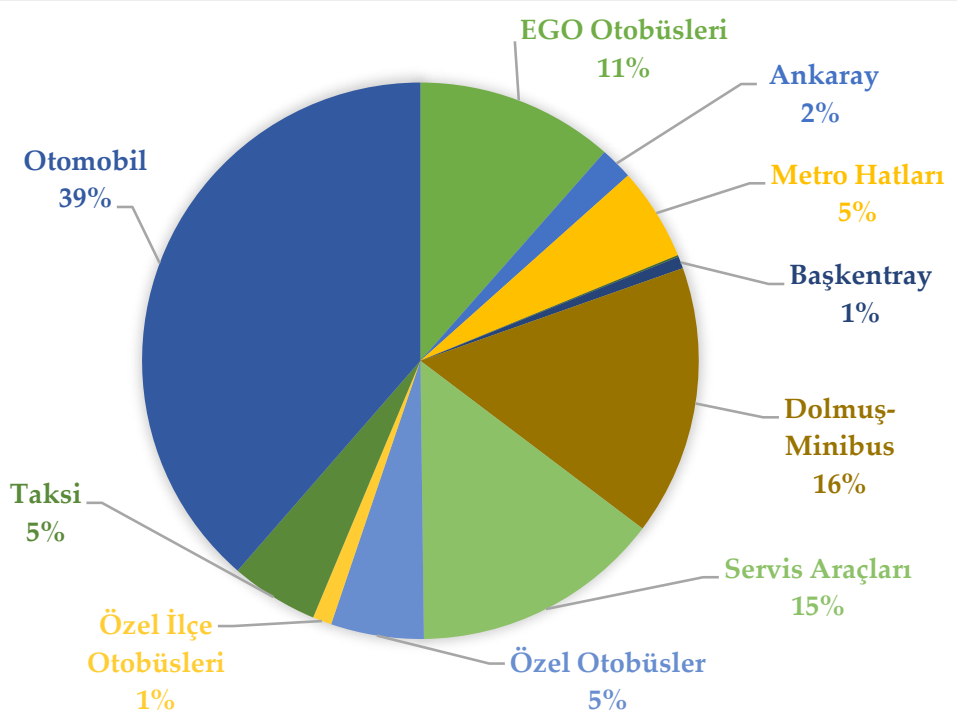

Şekil 1. Şubat 2020 Ankara kentsel ulaşım günlük yolcu oranları 


\section{İdari Önlemler}

Fiziksel temas, sonumum vb. yollarla bulaşabilen ve enfekte olan insan sayısının tüm dünyada ve Türkiye'de hızlı bir şekilde yükseldiği Covid-19 salgınına karşı Cumhurbaşkanlığı İçişleri Bakanlığı ve Ankara İl Umumi Hıfzıssıhha Kurulu (UHK) tarafindan 16 Mart 2020 tarihinden itibaren bir dizi idari önlem alınmıştır. ${ }^{10}$ Kişiler arası teması azaltmak ve sosyal mesafeyi korumak için ilk olarak (ilk ve ortaokullar ile liseler ve üniversitelerde) yüzyüze eğitim-öğretim faaliyetlerine ara verilerek uzaktan eğitime geçilmiştir. Kamu kurum ve kuruluşlarında çalışanlar için uzaktan çalışma, dönüşümlü çalışma gibi esnek çalışma uygulamaları başlatılmıştır. Hareketliliği en aza indirmek için 65 yaş ve üstü vatandaşlar ile kronik rahatsızlıklara sahip olanlardan başlanarak 20 yaş altı çocuklar ve gençler de dahil edilerek aralıklarla sokağa çıkma yasakları getirilmiştir. Ankara dahil 30 büyükşehir ile Zonguldak iline 4 Nisan 2020 tarihinde kara, hava ve deniz yolu ile yapılacak tüm giriş-çıkışlar 15 gün süre için durdurulmuş, bu giriş-çıkış kısıtlaması birkaç kez uzatılmıştır. Virüsün yayılımının hızlanarak vaka ve hasta sayısının ve tedavi gereksinimlerinin artarak halk sağlığı ile kamu düzenini ciddi şekilde etkileyebileceği gerekçesiyle, Ankara'da hafta sonları ve tatil günleri genel sokağa çıkma yasakları 11 Nisan 2020 tarihi ile uygulanmaya başlanmıştır.

Toplu taşıma sektöründe öncelikle yolcu kapasitelerinin \%50 oranında azaltılmasına ilişkin 24 Mart 2020'de karar alınmıştır. Sosyal mesafenin korunması açısından önemli olan bu karar, bir kaç kere değiştirilmiştir. Son olarak 8 Eylül 2020'de 'koltuk kapasitesi' kadar oturarak ve sadece iç hacim bak1mından fiziki mesafe kurallarının uygulanabileceği otobüslerde $\% 30$ oranında ve Ankaray, Metro ile Başkentray'da \%50 oranında ayakta yolcu alınmasına izin verilmiştir. Ticari taksilerin trafiğe çıkışlarında plakasının son hanesine göre 30 Mart 2020'de Ankara İl UHK tarafından sınırlamaya gidilmiş; ancak 5 Mayıs 2020 tarihinde uygulama sonlandırılmıştır. Ulaşım sektöründe en temel koruyucu önlem, 13 Nisan 2020 tarihinde getirilen tüm toplu taşıma araçları ile şehirlerarası ve ilçeler arası yolcu taşıyan ulaşım araçları, taksiler, her türlü ticari araçlar ve servis araçlarında maske kullanılması zorunluluğudur. Hastalığın doğrudan temas, dolaylı temas veya damlacık yolu ile iletimi açısından önemli olan yüz maskesi gibi kişisel koruyucu ekipman kullanımı,

\footnotetext{
${ }^{10}$ Bu idari önlemler, 2020-2021 dönemi Cumhurbaşkanlığı ve İçişleri Bakanlığ ${ }_{1}$ Genelgeleri, Ankara Valiliği İl Umumi Hıfzıssıhha Kurulu Kararları (UHKK) ile EGO Genel Müdürlüğü haberleri taranarak bir araya getirilmiştir.
} 
toplu taşıma ortamları dışında önce kamusal alanlarda özendirilse de ilerleyen süreçte il genelinde meskenler hariç tüm alanlarda istisnasız maske takma zorunluluğu getirilmiştir. Ankara ili toplu taşıma sistemini, kullanımını ve yolculukları doğrudan etkileyen idari önlemler tarihsel olarak Tablo 2'de verilmiştir. Şunu belirtmeliyiz ki toplu taşıma ortamları gibi diğer kamusal, yarı kamusal veya özel alanların kullanımına ilişkin çeşitli kısıtlar ilk vakanın tespitinden itibaren getirilmiş ve bu kararların çoğunun uygulanması salgının seyrine ve vaka sayılarına göre halen devam etmektedir.

Tablo 2. Covid-19 Pandemisine karşı Mart 2020 - Mart 2021 arası uygulanan toplu taşıma temelli idari önlemler*

\begin{tabular}{|c|c|c|}
\hline 16.03.2020 & $\begin{array}{l}\text { BİRİNCI DÖNEM- İdari Önlemler } \\
\text { İlk ve orta okullar ile liseler ve üniversitelerde eğitime } \\
\text { ara verildi ve uzaktan eğitime geçildi. }\end{array}$ & \\
\hline 21.03 .2020 & $\begin{array}{l}65 \text { yaş ve üstü vatandaşlar ile kronik rahatsızlıklara } \\
\text { sahip olanları ikametlerinden dışarı çıkmaları } \\
\text { yasaklandı. }\end{array}$ & $\begin{array}{l}\text { İçişleri Bakanlığ1 } \\
\text { 2020/5762 Genelgesi, } \\
\text { 21.03.2020/5 UHKK* }\end{array}$ \\
\hline 22.03 .2020 & $\begin{array}{l}\text { Kamu kurum ve kuruluşlarında çalışanlar için esnek } \\
\text { çalışma dönemi başladı. }\end{array}$ & $\begin{array}{l}\text { Cumhurbaşkanlığ } \\
\text { 2020/4 Genelgesi }\end{array}$ \\
\hline 24.03 .2020 & $\begin{array}{l}\text { Toplu taşıma araçlarının taşıma kapasitesinin \%50'si } \\
\text { kadar yolcu kabul etmelerine karar verildi. }\end{array}$ & 24.03.2020/7 UHKK \\
\hline 30.03 .2020 & $\begin{array}{l}\text { Ankara ilinde kayıtlı ticari taksilerin trafiğe çıkışları } \\
\text { plakasının son hanesine göre sınırlandırıldı. }\end{array}$ & 29.03.2020/14 UHKK \\
\hline 04.04 .2020 & $\begin{array}{l}20 \text { yaş ve altı çocuklar ve gençlerin sokağa çımaları } \\
\text { yasaklandı. }\end{array}$ & $\begin{array}{l}\text { İçişleri Bakanlığı } \\
\text { 2020/6235 Genelgesi, } \\
\text { 03.04.2020/17 UHKK } \\
\end{array}$ \\
\hline $11-12.04 .2020$ & Hafta sonu genel sokağa çıkma yasağı ilan edildi. & 10.04.2020/20 UHKK \\
\hline 13.04 .2020 & $\begin{array}{l}\text { Toplu taşıma araçlarında, taksilerde, her türlü ticari } \\
\text { araçlarda ve servis araçlarında maske kullanılmas } \\
\text { zorunluluğu getirildi. } \\
\text { Toplu taşıma araçlarında 'Yolcu oturma kapasitesinin' } \\
\% 50 \text { 'si kadar oturarak, uygun araçlarda ise } \% 25 \text { 'i kadar } \\
\text { da ayakta yolcu alınabilmesine karar verildi. }\end{array}$ & 12.04.2020/21 UHKK \\
\hline $18-19.04 .2020$ & Hafta sonu genel sokağa çıkma yasağı ilan edildi. & 16.04.2020/23 UHKK \\
\hline $23-26.04 .2020$ & 4 günlük genel sokağa çıkma yasağı ilan edildi. & 21.04.2020/25 UHKK \\
\hline 01-03.05.2020 & 3 günlük genel sokağa çıkma yasağı ilan edildi. & 29.04.2020/27 UHKK \\
\hline 05.05 .2020 & $\begin{array}{l}\text { Ticari taksilerin plakasının son hanesine göre trafiğe } \\
\text { çkış sınırlandırmasına son verildi. }\end{array}$ & 04.05.2020/29 UHKK \\
\hline 09.05 .2020 & $\begin{array}{l}\text { Taksi duraklarında ve ticari taksilerde sosyal mesafe } \\
\text { ve kişisel hijyene ilişkin önlemler belirlendi. }\end{array}$ & 09.05.2020/32 UHKK \\
\hline 09-10.05.2020 & Hafta sonu genel sokağa çıkma yasağı ilan edildi. & 07.05.2020/30 UHKK \\
\hline $16-19.05 .2020$ & 4 günlük genel sokağa çıkma yasağı ilan edildi. & 13.05.2020/34 UHKK \\
\hline 21.05 .2020 & $\begin{array}{l}65 \text { yaş ve üzeri vatandaşlara izin belgesi almak ve en } \\
\text { az } 30 \text { gün kalmak şartı ile seyahat izni verildi. }\end{array}$ & 21.05.2020/37 UHKK \\
\hline $23-26.05 .2020$ & 4 günlük genel sokağa çıkma yasağı ilan edildi. & 21.05.2020/37 UHKK \\
\hline 29.05 .2020 & $\begin{array}{l}\text { 18-20 yaş aralığındaki gençler için uygulanan sokağa } \\
\text { çkma yasağı kaldırıldı. }\end{array}$ & $\begin{array}{l}\text { İçişleri Bakanlığı } \\
\text { 2020/8483 Genelgesi, }\end{array}$ \\
\hline
\end{tabular}




\begin{tabular}{|c|c|c|}
\hline & & 29.05.2020/39 UHKK \\
\hline $30-31.05 .2020$ & Hafta sonu sokağa çkma yasağı ilan edildi. & 29.05.2020/39 UHKK \\
\hline 01.06 .2020 & $\begin{array}{l}\text { IKİNCI் DÖNEM-İdari Önlemler } \\
\text { Normalleşme süreci veya kontrollü sosyal hayat } \\
\text { başladı. }\end{array}$ & \\
\hline 01.06 .2020 & $\begin{array}{l}\text { Sokağa çıkma kısıtlaması devam eden } 18 \text { yaş ve } \\
\text { altındakilerin yanlarında velisinin bulunması şartı ile } \\
\text { şehir içi ve şehirlerarası yolculuk yapabilmelerine } \\
\text { karar verildi. }\end{array}$ & 31.05.2020/40 UHKK \\
\hline 01.062020 & $\begin{array}{l}\text { Toplu taşıma araçlarında koltuk kapasitesi kadar yolcu } \\
\text { taşınmasına ve yüz yüze gelinmeyecek şekilde birer } \\
\text { koltuk boş bırakılarak oturulmasına; } \\
\text { Minibüs, dolmuş ve servis araçlarında; İlçe özel halk } \\
\text { otobüslerinde ayakta yolcu alınmamasına; Belediye ve } \\
\text { şehir içi özel halk otobüslerinde ayakta yolcu } \\
\text { kapasitesinin \%30'u; Başkentray, Metro ve Ankaray'da } \\
\text { ise \%50'si kadar ayakta yolcu taşıyabilmelerine izin } \\
\text { verildi. }\end{array}$ & 01.06.2020/41 UHKK \\
\hline 10.06 .2020 & $\begin{array}{l}18 \text { yaş altı için sokağa çıkma kısıtlaması tümüyle } \\
\text { kaldırıldı. } \\
65 \text { yaş ve üzeri vatandaşların ise her gün 10:00-20:00 } \\
\text { saatleri arasında dışarı çıkabilmelerine izin verildi. }\end{array}$ & $\begin{array}{l}\text { İçişleri Bakanlığı } \\
\text { 2020/9138 Genelgesi, } \\
\text { 10.06.2020/46 UHKK }\end{array}$ \\
\hline 18.06 .2020 & $\begin{array}{l}\text { İl genelinde tüm açık alanlarda maske kullanımı } \\
\text { zorunlu hale getirildi. }\end{array}$ & 17.06.2020/48 UHKK \\
\hline $\begin{array}{l}20.06 .2020 \\
27-28.06 .2020\end{array}$ & $\begin{array}{l}\text { LGS ve YKS sınav günlerinde sırasıyla 09:00-15:00; } \\
\text { 09:30-15:00; ve 09:30-18:30 saatleri arasında sokağa } \\
\text { çıkmak kısıtlandı. }\end{array}$ & 19.06.2020/49 UHKK \\
\hline 10.07 .2020 & $\begin{array}{l}18 \text { yaş altındaki çocuk ve gençlerin şehir içi ve } \\
\text { şehirlerarası seyahatlerinde yanlarında velisi } \\
\text { bulunması şartı kaldırıldı. }\end{array}$ & $\begin{array}{l}\text { İçişleri Bakanlığı } \\
\text { 2020/11173 Yazısı ve } \\
\text { 10.07.2020/61 UHKK }\end{array}$ \\
\hline 08.09 .2020 & $\begin{array}{l}\text { İl genelinde (meskenler hariç) tüm alanlarda istisnasız } \\
\text { maske takma zorunluluğu getirildi. } \\
\text { Minibüs/midibüsler ile sosyal mesafe kurallarının } \\
\text { uygulanamayacağı şehir içi toplu taşıma araçlarında } \\
\text { ayakta yolcu alınması yasaklandı. }\end{array}$ & 08.09.2020/71 UHKK \\
\hline 21.09 .2020 & $\begin{array}{l}\text { Okul öncesi ve ilkokul 1'inci sinıflar için yüz yüze } \\
\text { eğitim belirli günlerde başladı. }\end{array}$ & $\begin{array}{l}\text { Milli Eğitim Bakanlığ } \\
\text { yazıları ve duyuruları }\end{array}$ \\
\hline 30.09 .2020 & $\begin{array}{l}\text { Şehir içi elektronik/akıllı toplu taşıma yolcu kartlarının } \\
\text { Sağlık Bakanlığı HES uygulaması ile } \\
\text { entegrasyonlarının sağlanmasına karar verildi. }\end{array}$ & 30.09.2020/74 UHKK \\
\hline 12.10 .2020 & $\begin{array}{l}\text { İlkokul 2, } 3 \text { ve } 4 \text { 'üncü sınıflar, ortaokul 8'inci sınıflar, } \\
\text { lise hazırlık ve } 12 \text { 'inci sınıflar, köy okulları ve özel } \\
\text { eğitim öğrencileri için yüz yüze eğitim belirli günlerde } \\
\text { başladı. }\end{array}$ & $\begin{array}{l}\text { Milli Eğitim Bakanlığı } \\
\text { yazıları ve duyuruları }\end{array}$ \\
\hline 16.11.2020 & $\begin{array}{l}\text { Organize sanayi bölgeleri, küçük sanayi siteleri ve } \\
\text { sanayi kuruluşları için mesai (ve vardiya) saatleri } \\
\text { 07:00-16:00 olarak düzenlendi. }\end{array}$ & 09.11.2020/79 UHKK \\
\hline 02.11 .2020 & $\begin{array}{l}\text { Ortaokul 5'inci sinıflar, lise 9'uncu sinıflar için yüz } \\
\text { yüze eğitim belirli günlerde başladı. }\end{array}$ & $\begin{array}{l}\text { Milli Eğitim Bakanlığ } \\
\text { yazıları ve duyuruları }\end{array}$ \\
\hline
\end{tabular}




\begin{tabular}{|c|c|c|}
\hline 10.11 .2020 & $\begin{array}{l}65 \text { yaş ve üzeri vatandaşların her gün 10:00-16:00 } \\
\text { saatleri dışında sokağa çıkmaları yasaklandı. }\end{array}$ & 10.11.2020/80 UHKK \\
\hline 11.11 .2020 & $\begin{array}{l}\text { Belirli cadde, sokaklar ve meydanlar ile toplu taşıma } \\
\text { araç durakları gibi alanlarda sigara ve tütün } \\
\text { mamullerinin tüketilmesi yasaklandı. }\end{array}$ & 11.11.2020/81 UHKK \\
\hline 17.11.2020 & 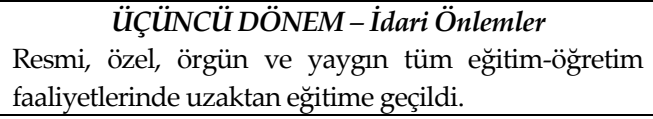 & \\
\hline 20.11 .2020 & $\begin{array}{l}65 \text { yaş ve üzeri vatandaşların gün içerisinde 10:00- } \\
\text { 13:00; } 20 \text { yaş altı çocuklar ve gençlerin 13:00-16:00 } \\
\text { saatleri dışında sokağa çıkmaları yasaklandı. }\end{array}$ & 18.11.2020/82 UHKK \\
\hline $21-23.11 .2020$ & $\begin{array}{l}\text { 21-22 Kasım saat 20:00-10:00 arası ve 22-23 Kasım saat } \\
\text { 20:00-05:00 arası sokağa ç1kmak yasaklandı. }\end{array}$ & 18.11.2020/82 UHKK \\
\hline 01.12 .2020 & $\begin{array}{l}\text { Hafta içi saat 21:00-05:00 arası; hafta sonları Cuma } \\
\text { 21:00- Pazartesi 05:00 arası sokağa çıma yasağı ilan } \\
\text { edildi. } \\
65 \text { yaş ve üzeri ile } 20 \text { yaş altı vatandaşların şehir içi } \\
\text { toplu taşıma araçlarını kullanmaları kısıtlandı. }\end{array}$ & $\begin{array}{l}\text { İçişleri Bakanlığı } \\
\text { 2020/20076 ve } \\
\text { 20077 Genelgeleri, } \\
\text { 01.12.2020/85 UHKK }\end{array}$ \\
\hline 03.12 .2020 & $\begin{array}{l}\text { Organize sanayi bölgeleri, küçük sanayi siteleri ve } \\
\text { sanayi kuruluşları için mesai (ve vardiya) saatleri } \\
\text { 08:00-18:00 olarak düzenlendi. }\end{array}$ & 03.12.2020/86 UHKK \\
\hline $\begin{array}{l}\text { 31.12.2020- } \\
01-04.01 .2021 \\
\end{array}$ & $\begin{array}{l}31 \text { Aralık } 2020 \text { Perşembe saat 21:00'den } 4 \text { Ocak } 2021 \\
\text { Pazartesi saat 05:00'a kadar sokağa çıkmak yasaklandı. }\end{array}$ & 15.12.2020/88 UHKK \\
\hline 15.02 .2021 & $\begin{array}{l}\text { Köy ilkokul ve ortaokullar ile tüm bağımsız ve özel } \\
\text { eğitim anaokullarında haftada } 5 \text { gün yüz yüze eğitim } \\
\text { başlandı. }\end{array}$ & $\begin{array}{l}\text { Milli Ĕ̆itim Bakanlığ } \\
\text { yazıları ve duyurular }\end{array}$ \\
\hline 02.03 .2021 & $\begin{array}{l}\text { 'YERINDE KARAR' DÖNEMI } \\
\text { İller } 4 \text { risk grubuna (düşük, orta, yüksek, çok yüksek) } \\
\text { ayrıldı ve idari önlemler esnetilerek gruplar özelinde } \\
\text { belirlendi. Ankara orta riskli bölge grubunda yer aldı. }\end{array}$ & 02.03.2021/11 UHKK \\
\hline
\end{tabular}

* Cumhurbaşkanlığı ve İçişleri Bakanlığı Genelgeleri ile Ankara Valiliği İl Umumi Hıfzıssıhha Kurulu Kararları (UHKK) taranarak hazırlanmıştır.

Genel olarak pandeminin 1 yıllık sürecini, hem salgının seyri hem de kontrol edici ve koruyucu önlemler ile yasaklar açısından, üç ana döneme ayırabiliriz. Birinci dönem, Mart ayının ikinci yarısında başlayan sıkı önlemler ile yasakların, özellikle Ankara ili dahil, 30 büyükşehir ve Zonguldak ili özelinde uygulandığı 15 Mart-31 Mayıs 2020 tarihleri arası dönemdir. Salgının birinci dalgası diyebileceğimiz bu dönemde en yüksek günlük vaka sayısına 13.976 vaka ile 11 Nisan 2020 tarihinde ulaşılmıştır. Hemen hemen mesken hariç sosyal mesafeyi tehdit edebilecek her türlü sosyal faaliyet geçici süreliğine bu dönemde durdurulmuştur. Öte yandan, evlere paket servis ve gel-al şeklindeki satışlar hariç, her türlü yeme-içme yerleri, kıraathane, kafe, çay ocakları, alışveriş merkezleri, berber, kuaför, spor salonları, yüzme havuzu, kaplıca, 
oyun salonları, lunaparklar, tiyatro, sinema ve konser salonları gibi yerlerdeki faaliyetler yasaklanmıştır. 1 Haziran 2020 tarihi itibariyle başlayan ikinci dönem, kişisel korunma başta olmak üzere temizlik, maske ve mesafe kurallarının devam ettiği ama kısıtların ve yasaklarının belirli bir derecede esnetildiği normalleşme veya kontrollü sosyal hayat dönemidir (Bknz. Tablo 1). Üçüncü dönem, Kasım 2020'nin ikinci yarısından itibaren birinci dönemdeki gibi hastalığın yayılımını kontrol altına almak için yeniden kısıtlar ve yasaklara dönüldüğü, sıkı önlemlerin alındığı dönemdir. 17 Kasım 2020'de başlayan ve 2 Mart 2021'e kadar devam eden salgının ikinci dalgası da diyebileceğimiz bu aralıkta en yüksek sayıya 8 Aralık'ta 33.198 vaka ile ulaşılmıştır. ${ }^{11} 21$ Eylül 2020 tarihinden itibaren kademeli bir şekilde okul öncesi, ilkokul, ortaokul ve liselerde belirli sinuflarda haftanın belirli günlerinde başlayan yüz yüze eğitim-öğretime yeniden ara verilmiş ve uzaktan eğitime geçilmiştir. 65 yaş ve üzeri vatandaşların gün içerisinde 10:00-13:00 saatleri; 20 yaş altı çocuklar ve gençlerin 13:00-16:00 saatleri dışında sokağa çıkmaları 20 Kasım 2020 kısıtlanmıştır. 'Seyahat İzin Belgesi' ile şehirlerarası yolculuk yapabilen 65 yaş ve üzeri vatandaşlar hariç ile şehir giriş-çıkışlarına ilişkin herhangi bir kısıt yeniden getirilmemiştir. 1 Aralık 2020 Saat 21:00'den itibaren hafta içi 21:00-05:00 saatleri arasinda ve hafta sonu Cuma saat 21:00'den pazartesi saat 05:00'a kadar genel sokağa çıkma kısıtlaması yeniden uygulanmaya başlanmıştır. Diğer taraftan da birinci dönemdeki gibi alışveriş merkezleri, berber ve kuaförler hariç ve spor salonları, yüzme havuzu ve kaplıcalar dahil sosyal faaliyete veya sosyal hayata ilişkin yerlerdeki faaliyetler durdurulmuştur.

2 Mart 2021 tarihi itibariyle salgını kontrol edici idari önlemler ve kısıtlar yeniden esnetilerek 'yerinde karar' dönemine geçilmiştir. İller 4 risk grubuna (düşük, orta, yüksek, çok yüksek) ayrılmış ve tedbir seviyeleri gruplara göre esnetilerek belirlenmiştir. Orta riskli bölge grubunda olan Ankara'da hafta içi ve hafta sonu sokağa çıkma kısıtlamasının 21:00-05:00 saatleri arasında uygulanmasına, 65 yaş ve üzeri ile 20 yaş altı genç ve çocukların sokağa çıkma kısıtlamasının kaldırılmasına karar verilmiş ve toplu taşıma araçlarını kullanabilmelerine izin verilmiştir. İlkokul, ortaokul ve liselerde belirli günlerde seyreltilmiş sınıflarda yüz yüze eğitime başlanılmıştır. Yeme-içme yerleri ile kıraathane ve çay bahçesi gibi işyerleri için kapasite oranları ve oturma düzenleri belirlenmiştir. Çoğu kamu ve özel işyerlerine girişte Hayat Eve Sığar (HES) kodu alınması

1131 Ağustos 2021 tarihi itibariyle günlük en yüksek vaka sayısı 63.082 ile 16 Nisan 2021 tarihinde ve vefat sayısı da 394 ile 30 Nisan 2021 tarihinde görülmüştür. 
zorunluluğu getirilmiştir. Bu görece 'normalleşme' dönemi 29 Nisan 2021 Perşembe günü saat 19:00'da başlayıp 17 Mayıs 2021 Pazartesi günü saat 05:00'te biten hafta içi hafta sonu ayrımı olmaksızın uygulanan 17 günlük 'tam kapanma' dönemine kadar devam etmiştir. Ardından tekrar kademeli olarak k1sttlar esnetilmiştir. 1 Haziran 2021 tarihi itibariyle bu 'kademeli normalleşme' döneminde ikinci aşamaya geçilmiş ve bu süreçte aşlama hizlanmıştır.

Salgın kontrol edici ve koruyucu idari önlemlerin uygulanmasına ilişkin kamu kurum ve kuruluşları ile özel işletmeler de önlemlerini artırmıştır. Ankara ili genelinde toplu taşıma hizmetlerini sunan Ankara Büyükşehir Belediyesi ilk olarak Kriz Merkezi Yönetimini kurarak Ulaşım Masası oluşturmuştur. Merkezi hükümet tarafından alınan idari önlemlerle eşzamanlı 65 yaş ve üstü vatandaşların serbest kart ve 20 yaş altı gençlerin indirimli yolcu kartı kullanımları askıya alınmıştır. Yenimahalle-Şentepe Teleferik Hattı kabinlerinin sosyal mesafeyi korumaya elverişli olmaması nedeniyle hizmete kapatılarak otobüs ile hizmet verilmeye başlanılmıştır. Mesai saatlerindeki değişiklikler doğrultusunda servis sıklıkları ve saatleri yeniden belirlenmiştir. Örneğin, organize sanayi bölgeleri, küçük sanayi siteleri ve sanayi kuruluşları için mesai başlangıç ve bitiş saatlerinde ulaşım sağlanabilmesi için saat 05:00-06:00 aralığında semtlerden şehir merkezine (Ulus-Sıhhıye-Kızılay istikametine) öncü servisler başlatılmış, mesai saatlerinin yeniden değsștirilmesiyle uygulama kaldırılmıştır.

Ankara Büyükşehir Belediyesi, sokağa çıkma kısıtlamasının olduğu zaman aralıklarında servis saatlerini ve seferlerini yeniden düzenleyerek kısttlamalardan muaf tutulan sağlık çalışanları, güvenlik görevlileri ile diğer vatandaşlara, ilçeler ile kapalı olan Ankaray ve Metro hatlarının güzergahlarında EGO otobüsleriyle hizmet vermeye devam etmiştir. TCDD Başkentray da belirli saatlerde faaliyet gösterirken güncellemelere ilişkin bilgilendirmeler de ‘EGO Cepte' ile yapılmıştır. Uygulamalar pandemi sürecinin üçüncü döneminde de devam etmiştir. 'Normalleşme' dönemi dahil sokağa çıkma yasakları dışındaki günler ve saatlerde sosyal mesafeyi korumak ve araç içi maksimum yolcu kapasitelerini sağlamak için 1540 otobüs filosu ile olağan kış/yaz servis programları ile Büyükşehir Belediyesi faaliyet göstermektedir. Ankaray ve Metro hatları da benzer bir şekilde seferlerini sürdürmektedir. Ancak Covid19 salgını, çalışma hayatını yavaşlatarak ve sosyal hayatı da hemen hemen durdurarak, hareketliliği büyük oranda mesken çevresi ile sınırlandırmış ve sokağa çıma kısıtlamalarıyla beraber engellemiştir. 


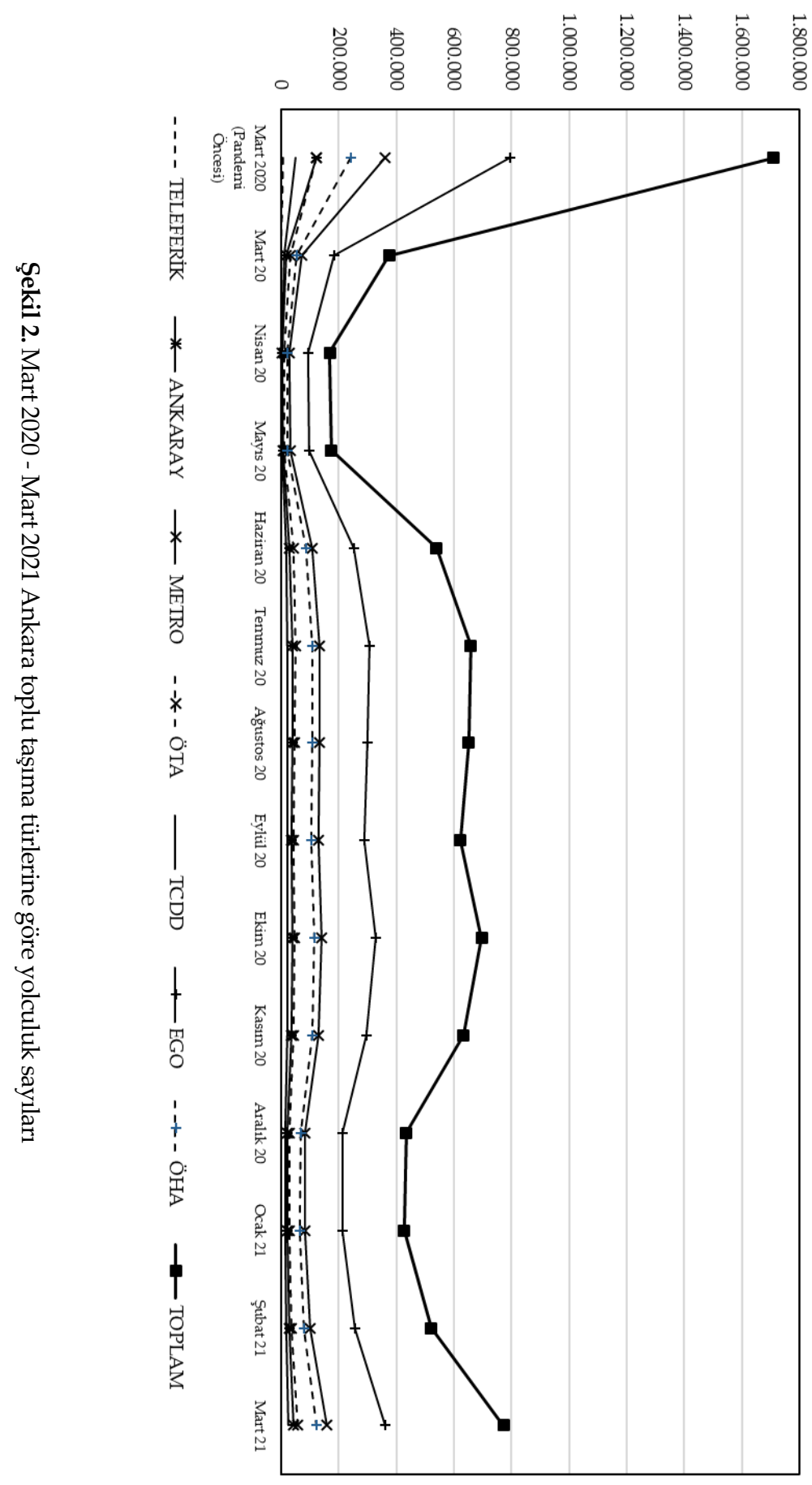


Şekil 2'de toplu taşıma yolculukları Covid-19 salgını öncesi karşılaştırma için 9 Mart 2020, Pazartesi gününü de içerecek şekilde 31 Mart 2021 tarihine kadar türlerine göre verilmiştir. Görüldüğü üzere salgının seyri ve dönemleri yolcu sayılarına da doğrudan yansımıştır. Birinci dönemde \%85-90 düzeyinde azalan toplu taşıma kullanımı ikinci dönemin başladığ 1 Haziran 2020 tarihi itibariyle belirli bir düzeyde artmış ve sıkı önlemler ile yasakların yeniden uygulanmaya başlandığ 1 üçüncü dönemde tekrar azalmıştır. Ulaşım türlerinin kullanım oranları genel olarak korunarak, benzer dalgalanma tüm türler için gözlenmiştir. Şekil 3'teki kutu-çizgi grafiği ise Mart 2020'den itibaren toplu taşıma yolculuklarının aylık değişimini göstermektedir. Kutunun alt sınırı $\% 25$ 'inci veri noktasını, içindeki yatay çizgi ortancayı, üst sınırı ise \%75'inci veri noktasını; dışındaki çizgi ise çeyrekler arası farkın 1,5 katı aralığa düşen verileri içermektedir. Artı işareti uç değerleri ifade etmektedir. Uç değerlerle beraber minimum ve maksimum değerler bir ay içinde toplu taşıma kullanımının hangi aralıkta kaldığını açıklamaktadır

Şekil 3'teki grafikten salgının seyri ve önlemlerin dönemleri, dönemler arası geçişler ile yolcu sayılarındaki değişkenlik (varyasyon) açıkça okunmaktadır. Kısıtlamaların yoğun olduğu ve bilinmezliklerin çok olduğu birinci dönemdeki Nisan ve Mayıs 2020 ayları diğer aylardan farklılaşmaktadır. Toplu taşıma kullanımı en alt düzeyine inmiştir. Haziran-Kasım 2020 arasını kapsayan 'normalleşme' döneminde ise yolculukların arttğı takip edilmekte ve Eylül ayı ortasında küçük bir düşüş gözlenmektedir. Yazın sonlanması, KPSS sınavları ile 21 Eylül 2020 tarihinden itibaren yüz yüze eğitime kademeli olarak başlanılması bu dönemindeki Eylül öncesi ve sonrası iki dalgayı açıklayabilir. Üçüncü dönemde ise toplu taşıma yolculukları yeniden azalmış, hafta içi gece saatleri ile hafta sonu sokağa çıkma kısıtlamaları nedeniyle günlük değerlerdeki dalgalanma artmıştır. Bu dönemde 65 yaş üstü ve 20 yaş altı vatandaşların şehir içi toplu taşıma araçlarıyla seyahat etmeleri yeniden kısıtlanmıştır. Yolculuk sayılarındaki düşüş ile hafta içi ve hafta sonu arasındaki farklar, kutu boyutlarından ve çizgilerden anlaşılsa da Şekil 4'te toplu taşıma yolculuklarının günlük değerleri ayrıca verilmiştir. M1-M2-M3 Metro hatlarının işletme programları/zaman ve sefer çizelgesi örnek teşkil etmesi amacyyla Tablo 3'te sunulmuştur. 


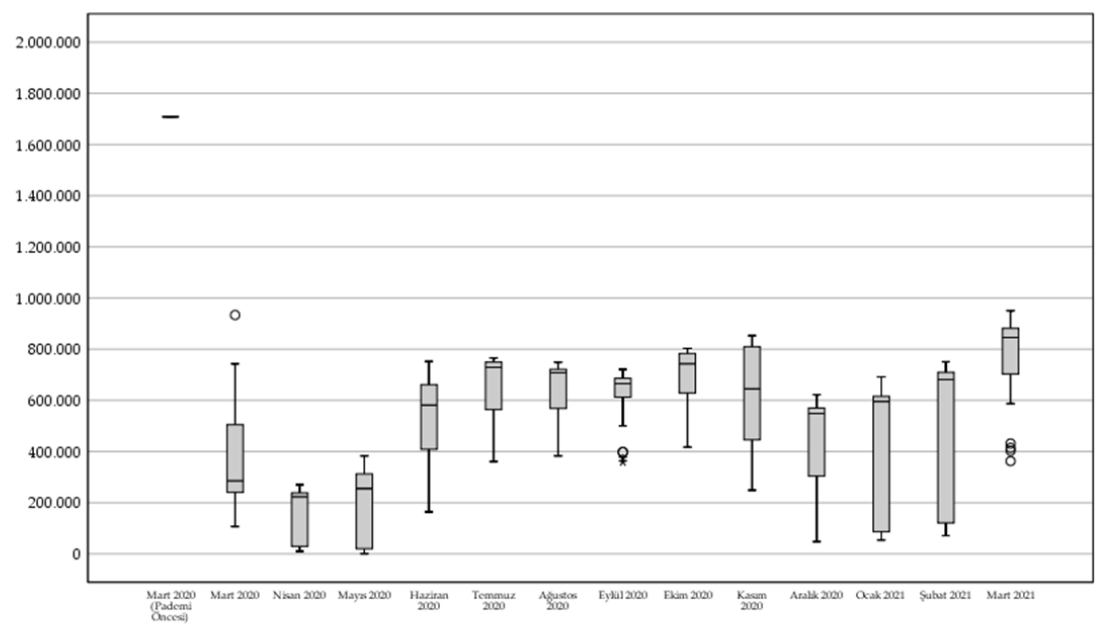

Şekil 3. Mart 2020 - Mart 2021 Ankara aylık toplu taşıma yolculukları

\section{Teknik Önlemler}

Pandemiye yönelik toplu taşıma sistemlerini de ilgilendiren önlemler her ne kadar kamu kurum ve kuruluşları tarafından hızlı bir şekilde belirlenmiş olsa da etkili olabilmeleri toplu taşıma sistemi çalışanları ve yolcularının uyumuna bağlıdır. Uzun vadede hareketlilik tamamen engellenemeyeceği için salgın kontrol altına alınana kadar geçici çözümler olarak görülse de Ankara Büyükşehir Belediyesi de öncelikle çalışanların ve yolcuların güvenliğini sağlamaya yönelik teknik önlemler geliştirerek uygulamıştı. ${ }^{12}$ İlk olarak toplu taşıma ortamları, araçları ve hizmet binalarında dezenfeksiyon ve sterilizasyon çalışmaları artırılmış ve kuru hava yöntemi (pulvarize yöntemi) kullanılmaya başlanmıştır. Raylı sistem istasyonlarına sensörlü el dezenfektan üniteleri turnikelerin olduğu noktalara yerleştirilmiştir. Her ne kadar yaşanmakta olan Covid-19 pandemisi süresince hangi dezenfektanın ve ekipmanın kullanılacağından, hangi sıklıkla ne tür yüzeylerin temizleneceğine ilişkin ortak bir görüş geliştirilememiş olsa da Ankara Büyükşehir Belediyesi 6 Nisan tarihinde Ankaray ve Metro vagonların her seferden sonra ASKİ tarafindan üretilen sodyum hipokloriti kullanarak temizlemeye başlamıştır. Bununla beraber günlük yaklaşık 1.320 EGO Otobüsünün iç-dış temizliği yapılarak dezenfektasyonu yapılmaktadır (Şekil 5).

\footnotetext{
${ }^{12}$ Bu teknik önlemler, 2020-2021 dönemi EGO Genel Müdürlügü haberleri taranarak bir araya getirilmiştir.
} 

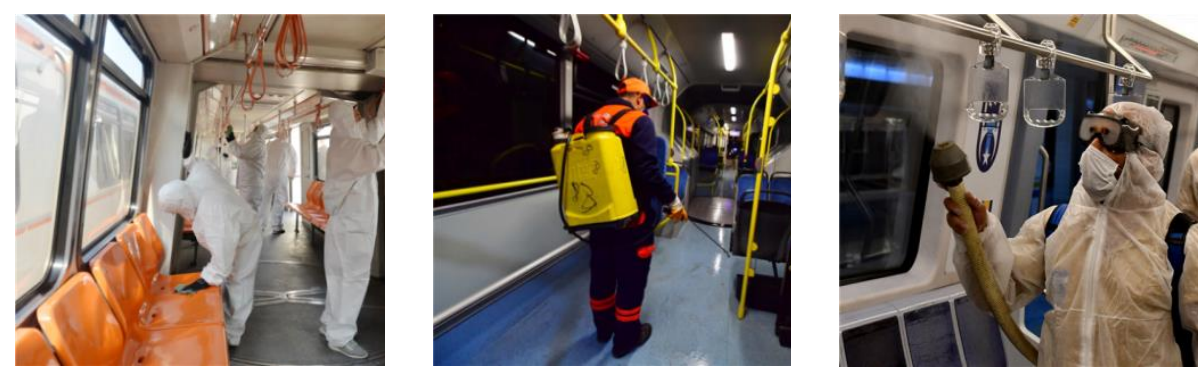

Şekil 5. Toplu taşıma araçlarında temizlik ve dezenfeksiyon çalışmaları (EGO, 2021)

Salgınının önlenmesine yönelik tedbirler kapsamında Ankaray, Metro ve EGO Otobüslerinde bulunan klimalar, 20 Mart 2020 tarihinden itibaren kapatılmıştır. Daha sonra Sağlık Bakanlığı Bilimsel Danışma Kurulu'nun yayımlanladığı "Covid-19 Salgın Yönetimi ve Çalışma Rehberi"nde belirtilen hususlar da dikkate alınarak metro vagonlarında teknik düzenlemeler yapılmış ve iç hava dolaşımı yerine dışarıdan alınan temiz hava ile klimaların çalışması sağlanmıştır. Ankaray ve otobüslerde ise havalandırma işlemi açlabilir pencelerle devam etmiştir. EGO Genel Müdürlüğü, sosyal mesafenin uygulanabilmesi adına duyarlılık oluşturabilmek için 'Sağlığın için mesafeni koru, koltuğu boş bırak' yazılı çıkartmaları otobüslerin koltuklarına yapıştırmıştır. Buna ek olarak Ankaray ve Metro vagonları dahil otobüslere yolcu taşıma kapasitesine ilişkin bilgilendirme etiketleri ile yolcuların birbirlerine en az 1 m. mesafe bırakmalarını sağlayacak zemin çıkartmaları yerleştirmiştir (Şekil 6). 01.06.2020/41 sayılı Ankara İl UHKK gereği Ankaray'da koltuklarda tadilat yapılarak 'dörtlü karşılıklı oturma düzeni' de kaldırılmıştır.
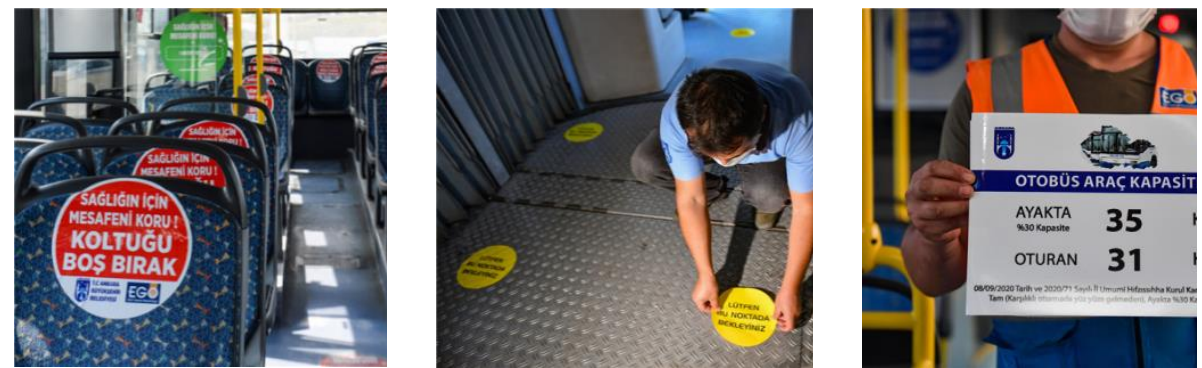

Şekil 6. Toplu taşıma araçlarında koltuk ve zemin çıkartmaları ile yolcu kapasite bilgilendirme etiketleri (EGO, 2021)

Araç sürücülerini korumak ve yolcu ile şoför arasındaki teması mümkün olduğunca en aza indirmek için öncelikle EGO otobüslerinde sürücü bölümüne şeffaf paravan yerleştirilmiştir. Diğer yandan Ankara Büyükşehir Belediyesi 
öncülüğünde taksi, dolmuş ve servis araçlarında başlatılan şeffaf kabin uygulaması EGO otobüslerine de genişletilmiştir (Şekil 7). Benzer bir şekilde toplu taşıma araçlarında 13 Nisan 2020 tarihinden itibaren dezenfektan ürün bulundurma zorunluluğu getirildiğinden Büyükşehir Belediyesi özel halk otobüsleri ile özel toplu taşıma araçlarına da dezenfektan ürün dağıtmıştır. Yüz yüze iletişimi ve nakit para işlemlerini azaltmak için Ankarakart İşlem Merkezlerinin çalışma saatleri geçici olarak değiştirilmiş ve bakiye yükleme 'Başkent Mobil ve EGO Cepte' uygulamasına diğer işlemler de online 'www.ankarakart.com.tr' adresine yönlendirilmiştir. Öğrenci kartlarının vize işlemleri ise raylı sistem istasyonlarında bulunan Smart ve Mini bankolardan ücretsiz olarak yapılabilmiştir. Bunlara ek olarak, Sağlık Bakanlığı'nın hastalık riskini içeren HES uygulamasına dahil olması ve şehir içi ile şehirlerarası toplu ulaşımda kullanımı için seyahat kartları ile kişiselleştirilmesi bu süre içinde önem kazanmıştır.
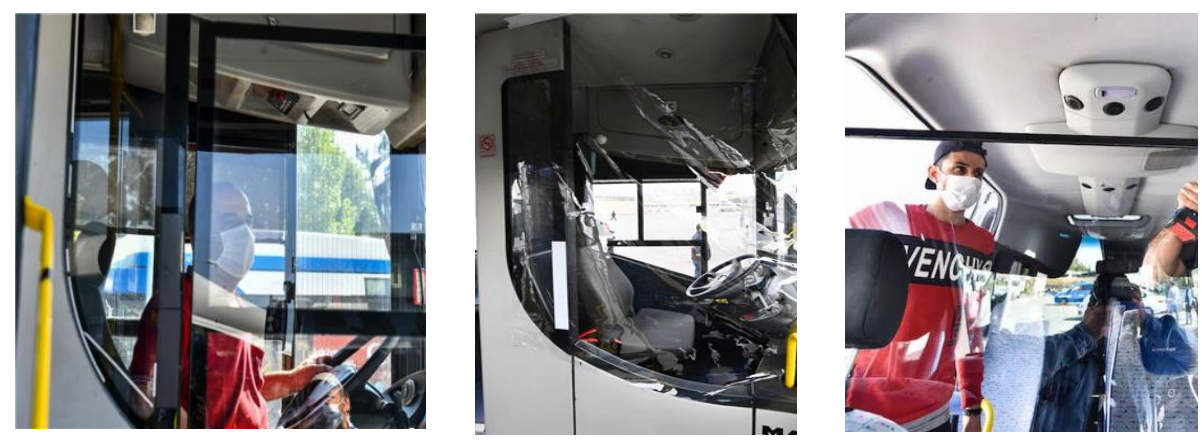

Şekil 7. Toplu taşıma araçlarında şeffaf paravan ve kabin uygulaması (EGO, 2021)

Uzun vadede bulaşıcı hastalıklara karşı, toplu taşıma sistemi ile yolcu hareketliliğinin değişen özelliklerine göre farklı senaryoları gözeten etkili ve kalıcı önlemlerin alınması gerekirken Türkiye'de de merkezi ve yerel yönetimler birden ortaya çıan ve hızla yayılan Covid-19 pandemisiyle karşı karşıya kalmışlardır. Hastalığının yayılımını kontrol etmek için genel sokağa çıkma yasaklarıyla beraber toplu taşıma kullanımına ilişkin kısıtlar hızlıca uygulanmıştır. Araç içi yolcu kapasitelerinin düşürülmesi de idari önlemler arasındadır. Süreç içinde maske takma, temaslı yüzeylerin dezenfeksiyonu, iyi havalandırma ve havanın tazelenmesi dünyada ve Türkiye'de ön plana çıkmıştır. İlk vakanın tepitinden sonraki döneminde insanlar risk almamış ve toplu taşıma dahil tüm kamusal alanlarından uzaklaşmıştır. 'Korku' dönemi de di- 
yebileceğimiz bu dönemden sonra bilinmezlikler azaldıkça ve önlemler alındıkça artan vaka sayılarına rağmen toplu taşıma kullanımı olumlu bir şekilde artmış ve artış seyrini sürdürmektedir.

\section{Sonuç}

Yolculuklar tarih boyunca bulaşıcı hastalıkların ortaya çıkışını ve yayılımını etkilemiştir. Ancak geçtiğimiz on yıllar boyunca planlama, tasarım ve halk sağlığı kesişimleri bulaşıcı hastalıklara daha az, kronik hastalıklara, saldırılara ve afetlere daha çok odaklanmıştır (Forsyth, 2020). Aslında sadece 21. YY. kendisi bile SARS, MERS ve Ebola gibi bulaşıcı hastalıkların yarattığı çeşitli tehditlere tanık olmasına rağmen bir virüsün tüm dünyayı kısa sürede bu hızla sararak etkisiz hale getirebileceği öngörülememiştir. Diğer taraftan kentler sürekli dinamik, doğrusal olmayan, açık ve sürekli evrilen, içinde oluşları ve çatallanmaları barındıran ve beklenmedik durumlar yaratan karmaşık sistemler olarak tanımlanmaktadır (Yetişkul, 2017). Kentler enerji, mal, bilgi ve insan akışlarının oluşturduğu sonsuz ağdan oluşan sistemlerdir. Hayal bile edilemeyen karmaşıklık düzeyi ile oluşan bu ağlar aynı zamanda çok hassas sistemler ortaya çıkarmaktadır. Küçük bir değişiklik bu dinamik sistemde çok büyük değişikliklere ve yeni durumlara sebep olabilmektedir. Batty (2020) 'Koronavirüs krizi: Pandemi sonrası şehir nasıl görünecek?' adlı makalesinde bu düşüncenin ilk defa hava durumundaki beklenmedik etkiler için 1972 yılında Edward Lorenz tarafından 'Brezilya'daki bir kelebeğin kanat çırpışları Teksas'ta bir kasırgaya yol açar mı?' sorusuyla açı bir şekilde söylendiğine dikkat çekmiştir. Çin'in Wuhan kentindeki bir pazarda rastgele ortaya çıan bu bilinmeyen virüsün küresel bir kilitlenmeye sebep olması da çok farklı bir örnek değildir.

Yerel ölçekten küresel ölçeğe seyahat ve tedarik zincirlerinin bu derecede bağlantılı olduğunu bilmemiz veya bu düzeyin bildiğimizin üzerinde olması maalesef Covid-19 hastalığının yayılımını yavaşlatmayı veya salgını kontrol altına almamızı kısa dönemde sağlayamamıştır. Ne yazık ki, bulaşıcı hastalıkların yayılmasına karşı savunmasızlığa katkıda bulunmuş olabilecek ulaşımla inşa edilmiş çevrenin planlanması, tasarlanması, inşaası, yönetimi ve işletimi pandemi ile beraber yeniden ön plana çıkmış ve gelecek için önemli soruları gündeme getirmiştir. Bu noktada önemli olan kentlerimizin ulaşım altyapısını çok yönlü bir halk sağlığı güvenliği ile beraber bulaşıcı hastalıklara ve tehditlere karşı hazırlıklı kılmaktır. Covid-19 vakalarının görülmeye başlamasıyla hızlı bir şekilde karar alınarak uygulamaya konulan idari önlemler, yasaklar, teknik önlemler ile kişisel korunma içinde yaşadığımız bu 
günlerde de farklılaşarak uygulanmaya devam etmektedir. Ancak bu hızlıca yerinde alınan doğru kararlar ve önlemler yolcuların güvenlik duygusunu karşılamıyor veya bulaş riskine karşı algısını değiştirmiyorsa yolcuların toplu taşıma kullanımında kaçınarak otomobil kullanımına yöneleceği de açıktır. 2010 ile 2019 yılları arasında bin kişiye düşen otomobil sayıları Şenbil ve Yetişkul (2020) tarafından iller bazında karşılaştırılmış ve Ankara'nın açık ara ile geride kalan 80 ilden ayrıştığı gösterilmiştir. Bu çalışmada Ankara'nın otomobilleşme düzeyi, 2020 verileriyle tekrar ele alınmıştır. Son on yılın verisi kullanılarak illerdeki otomobil sayısını (2010-2019 yılları arası esas alınarak) tahmin edilen doğrusal artışı ile 2020 yılı için gerçekleşen artış karşılaştırıldığında, en büyük artışın Ankara ilinde olduğu bulunmuştur. Ankara'da 2020 yılındaki otomobil sayısındaki artss, tahmin edilenden 28.54 fazladır. (Ankara'yı 1.49 otomobil ile Antalya izlemektedir.) Ankara' daki bu hızlı arabalaşma gösteriyor ki Covid-19 hastalığının yayılımın kontrol etmek amaciyla uygulanan önlemlere benzer ve pandemi döneminde olduğu kadar pandemi sonrası iyileşme döneminde de toplu taşıma kullanımını desteklemek için ek önlemlerin alınması ve yeni stratejiler ile politikaların geliştirilmesi gerekmektedir.

Yolcu sayısındaki dramatik düşüşten ve ek sağlık önlemlerinin maliyetlerinden büyük ölçüde etkilenen gelirine rağmen Ankara toplu taşıma sistemi hizmet ağını ve düzeyini pandemi-sonrası döneme uyarlamak zorundadır. Operasyonel kapasiteyi artırmak, doluluk oranlarını yönetmek için ilk akla gelen uygulama olsa da taşıma arzını talebe göre uyarlamak ve talebi yönetmek uzun vadede güvenli toplu taşıma için daha önemlidir (UITP, 2020). Gerçek zamanlı platform veya durak yoğunluklarıyla servis sıklıkları düzenlenebilir. Yapay zeka ve nesnelerin internetinden faydalanılarak proaktif olarak bulaşma riski tespit edilrek kontrol edilebilir (WEF, 2021). Buna ek olarak, pandemi boyunca alınan çeşitli önlemlerin toplu taşıma kullanımına etkileri ve bu uygulamalara karşı kullanıcıların verdiği tepkiler detaylıca araştırılarak yolcu davranışlarındaki değişiklikler belirlenebilir. Böylece, farklı kullanıcıların davranış biçimleri ortaya çıkartılır ve talep yönetilebilir. Örneğin, doğrudan yasaklarla bulaşı kontrol etmek yerine belirli günlere ve saatlere özel veya kullanıcı gruplarına özel bilet fiyatlandırma seçenekleri oluşturmak zirve saatlerini ve doluluk oranlarını yönetmemizi sağlayacaktır.

Mevcut altyapıyı iyi kullanarak ve gerekirse yeni teknolojilere yatırım yaparak kullanıcılara gerçek zamanlı bilgiyi sürekli aktarmak toplu taşımaya güveni artıracaktır. Küresel ölçekli bir anket, bazı şehirlerde insanların üçte birinin toplu taşıma araçlarına geri dönmekten çekindiğini ortaya koymuştur 
(WEF, 2021). Pandemi döneminde başlayan temizlik ve dezenfeksiyon işlemlerinin sürdürülmesi, iyi/doğal havalandırmanın tüm toplu taşıma ortamlarında sağlanması ve temassız ödeme imkanlarının yaygınlaştırılması güven ortamını yaratmada önemlidir. Buna ek olarak toplu taşıma kullanımını caydırmamak için toplu taşıma ortamlarının hastalığın bulaşma olasılığını ne derecede etkilediği araştırmalarla daha açık bir şekilde ortaya konulmalıdır. Daha çok bilgi doğru önlemlerin alınmasını sağlayarak toplu taşımaya güveni artıracaktır. Bireylerin de günümüzde hareketliliği tamamen durdurmanın veya halk sağlığı açısından sıfır risk düzeyine inmenin mümkün olmadığını anlaması ve yaşamın sürdürülebilirliği için toplu taşıma kullanımından kaçınılmaması ve kurallara uyarak kişisel korunmaya özen göstermesi gerekmektedir.

Tablo 3. Ankara Metro İşletmesi M1-M2-M3 Hattının Mart 2020 - Mart 2021 Tren İşletme Programi*

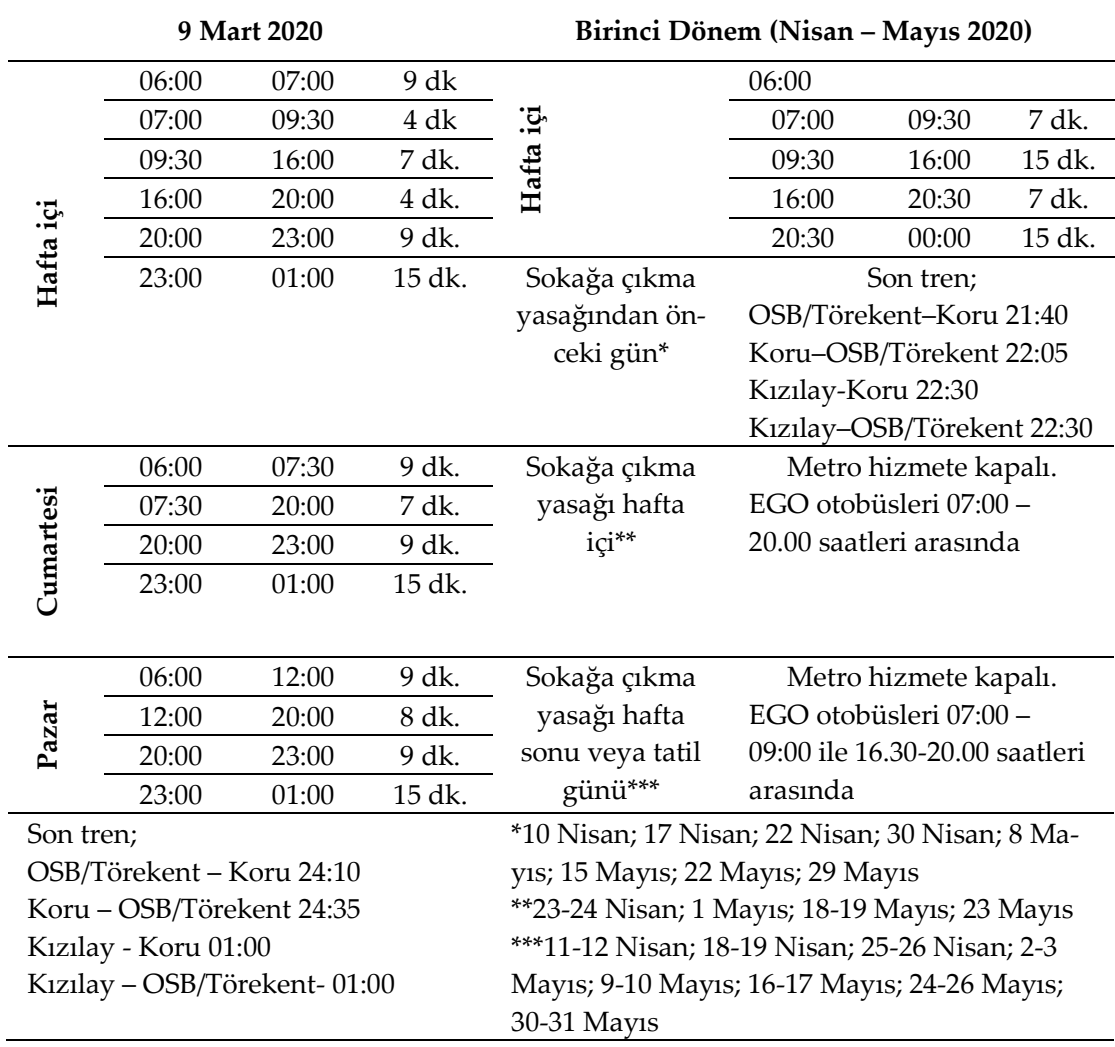




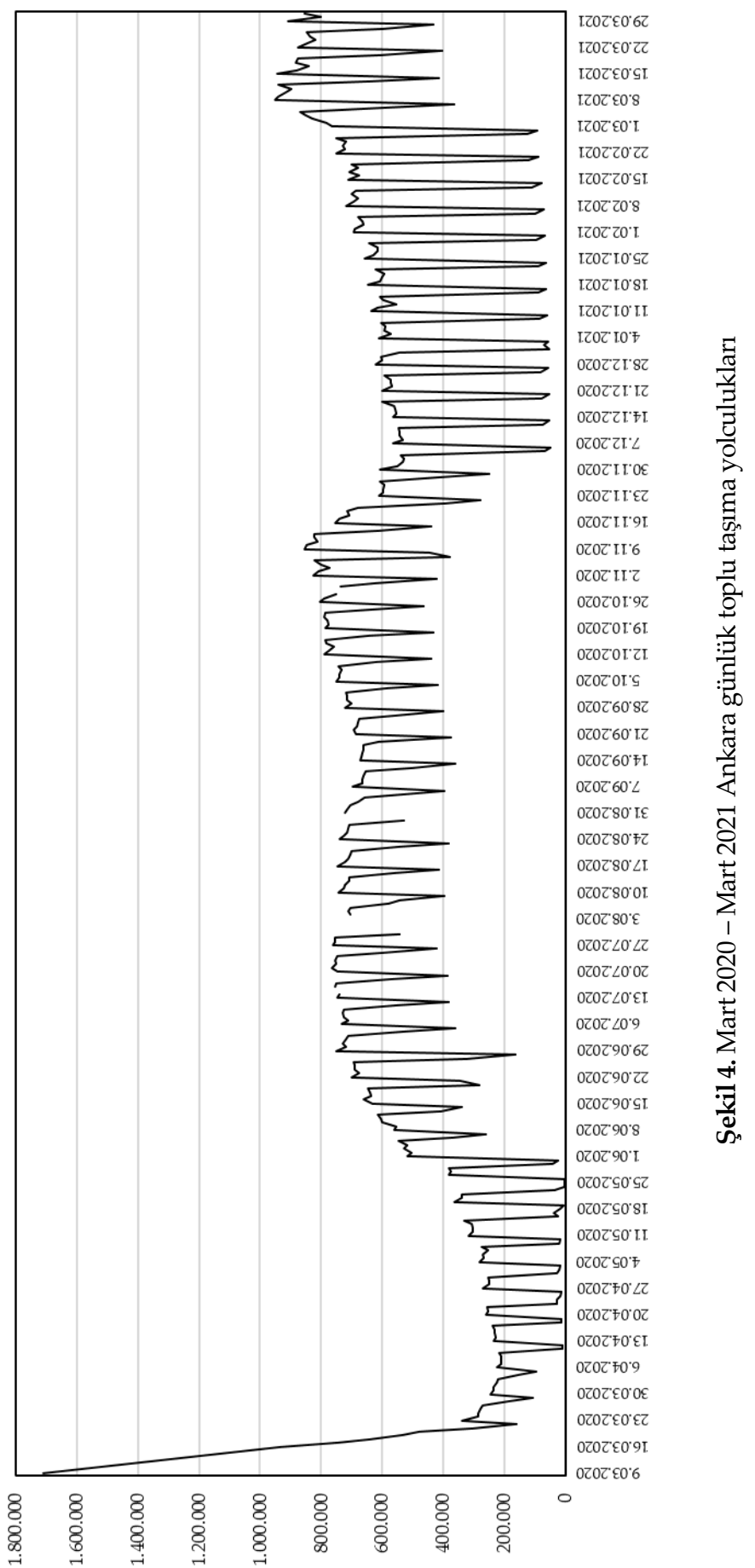




\section{Extended Abstract}

\section{Urban Transport, Pandemics and Covid-19: Ankara Public Transit System}

\author{
Hind Shahin \\ ORCID: 0000-0003-4524-1986
}

\author{
Emine Yetişkul \\ ORCID: 0000-0003-0829-1562
}

The first human cases of Covid-19, the disease caused by the novel coronavirus were reported in Wuhan City of China in December 2019. However, the disease quickly spread to other regions of the world and was declared as a Public Health Emergency of International Concern by WHO on January 30, 2020. One after the other, authorities took various pharmaceutical and nonpharmaceutical actions in an effort to curb the spread of the virus and to flatten the curves of cases and deaths. Majority of non-pharmaceutical actions resulted in severe limitations to people's mobility reducing passenger transportation to its lowest levels. Accordingly, public transportation systems took the hardest hit worldwide. Thus, a body of research emerged on the impact of Covid-19 on public transportation systems worldwide. This paper aims to contribute to the growing body of research by analyzing the effect of Covid19 on the public transit system in Ankara, Turkey. One-year time interval of Covid-19 Pandemic from March 11, 2020 when the first case was detected in Turkey is evaluated by detailing various non-pharmaceutical measures taken by central and local governments to combat the threat of the pandemic. To do so, positive relationships between pandemics and trips in the context of urban transportation are introduced firstly. Then factors affecting disease spread are briefly explained. Measures for controlling spread, and protecting passengers and employees are discussed along with international examples to evaluate Ankara's public transit system.

Transmission and spread of airborne diseases in the built environment, including transportation systems, depend on a series of sequential interactions between patients, carriers, users of the environment, and characteristics of physical environment (Faass et al., 2013). Current literature on this subject 
provides us with basic information about factors affecting risk of exposure to biohazards. These factors are generally grouped under pathogen transmission ways, nature and design of public transportation system, and passenger mobility behavior. Even though the quantitative impact of each on the others or disease spread remains largely absent from literature, it is possible to develop short and long-term strategies and policies for prevention measures for epidemics according to these factors. Research and practice have successfully identified three categories of control measures necessary to break the chain of disease transmission in artificial environments, including that of public transit. This paper focuses on the creation and maintenance of healthy public transport infrastructure through the adoption of administrative, technical and personal protection measures. Still, preventing and responding to biological threats in transport environments is complex and necessitates a multidisciplinary approach to design and implement appropriate prevention measures (Nasir et al., 2016). Besides, breaking the chain of infection transmission on public transportation systems is necessary for maintaining aspects of public health other than safety from infectious diseases.

In this paper, a detailed picture of the public transit in Ankara before and after the start of the pandemic is offered. Based on the period from March 2020 to March 2021, it is quite clear that Covid-19 had a significant negative impact on public transit ridership and mobility behavior in Ankara. The graphs and tables are given to show ridership loss, daily and monthly change in total public transit trips and schedules. Decrease in ridership fluctuated across different days and months of period covered in line with different control measures adopted to combat the pandemic. In general, one-year pandemic period was divided into three, parallel to the increase/decrease in case load and restriction/ease of protective measures and prohibitions. The first period from the second-half of March 2020 to end of May 2020 covers the 'first wave' of the pandemic during when strict measures were taken and many prohibitions were applied. The second period started with the beginning of June 2020 is the normalization period when measures were continued but some prohibitions were relaxed. In an attempt to slow the spread of Covid-19 'second wave', the third period starting from the mid-November 2020 is similar to the first period in terms of measures and restrictions.

The prevention measures in Ankara include administrative measures such as curfews throughout day and between certain hours, age-based mobility restrictions (i.e. residents below 18 and above 65 years of age), suspension of face-to-face education at schools and universities, introduction of flexible and 
hybrid working schedules. In addition to these restrictions that affected mass transportation indirectly, specific measures (e.g., limiting seated and standing passenger-capacity, introducing mandates on mask wearing, and integrating smart cards with 'Life fits into Home" codes that carries personal disease status) were also taken to reduce interpersonal contact and maintain social distance in mass transportation. On the other hand, Ankara Metropolitan Municipality adopted technical measures regarding the threat of Covid-19 on Ankara's public transit. Disinfection routines were increased in vehicles, stations and stops and air conditioners were turned off in public buses (EGO) and light rail (Ankaray) and metro systems at first. Operation of air conditioners in metro vehicles was later ensured with the fresh air taken from outside instead of indoor air circulation. In order to protect drivers and minimize contact with passengers, transparent covers were placed in the driver sections of public buses. In fact, many measures and restrictions on the use of public transit were quickly implemented by central and local governments to control the spread of the disease in parallel to international examples. However, it is necessary to take effective and permanent measures against infectious diseases in the long term, taking into account different scenarios according to the changing characteristics of the public transport system and passenger mobility. Otherwise, passengers will continue to avoid using public transit and switch to automobile use. The increase in car ownership in Ankara was more than expected in 2020, implying the necessity of additional measures that should be taken to support the use of public transport during normalization or recovery periods afterwards.

\section{Kaynakça/References}

Ahmad, A., Krumkamp, R. ve Reintjes, R. (2009). Controlling SARS: A review on China's response compared with other SARS-affected countries. Tropical Medicine \& International Health, 14, 36-45.

Al Hajjar, S., Memish, Z.A. ve McIntosh, K. (2013). Middle East Respiratory Syndrome Coronavirus (MERS-CoV): A perpetual challenge. Annals of Saudi Medicine, 33(5), 427-36.

Andrews, J.R., Morrow, C. ve Wood, R (2013). Modeling the role of public transportation in sustaining tuberculosis transmission in South Africa. American Journal of Epidemiology, 177(6), 556-561.

Batty, M. (2020). The Coronavirus crisis: What will the post-pandemic city look like? EPB: Urban Analytics and City Science, 47(4), 547-552. 
Boyce, J.M. (2016). Modern technologies for improving cleaning and disinfection of environmental surfaces in hospitals. Antimicrobial Resistance $\mathcal{E}$ Infection Control, 5(10).

Browne, A., Ahmad, S., Beck, C.R. ve Nguyen-Van-Tam, J.S. (2016). The roles of transportation and transportation hubs in the propagation of influenza and coronaviruses: A systematic review. Journal of Travel Medicine, 23(1), tav002.

Casey, A.L., Adams, D., Karpanen, T.J., Lambert, P.A., Cookson, B.D., Nightingale, P., ... Elliott, T.S.J. (2010). Role of copper in reducing hospital environment contamination. Journal of Hospital Infection, 74(1), 72-77.

Cossar, J.H. (1994). Influence of travel and disease: An historical perspective. Journal of Travel Medicine, 1(1), 36-39.

Davies, J.C. (2007). EPA and nanotechnology: Oversight for the 21st century. Washington, D.C.: Woodrow Wilson International, Center for Scholars.

DfT, Department for Transport (2011). London and South East 'top ten' overcrowded train services: Spring 2011. Erişim adresi: https://www.gov.uk/government/publications/london-and-south-east-top-ten-overcrowded-train-services

Edelson, P.J. ve Phypers, M. (2011). TB transmission on public transportation: A review of published studies and recommendations for contact tracing. Travel Medicine and Infectious Disease, 9(1), 27-31.

eHealth Network (2913). World's first antimicrobial copper train. Erişim adresi: https://ehealth.eletsonline.com/2013/10/worlds-first-antimicrobial-coppertrain/

Faass, J., Greenberg, M. ve Lowrie, K.W. (2013). Defending a moving target: H1N1 preparedness training for the transit industry. Health Promotion Practice, 14(1), 24-29.

Feske, M.L., Teeter, L.D., Musser, J.M. ve Graviss, E.A. (2011). Giving TB wheels: Public transportation as a risk factor for tuberculosis transmission. Tuberculosis (Edinb), 91(1), 16-23.

Forsyth, A. (2020). What role do planning and design play in a pandemic? News - Harvard University Graduate School of Design 2020.

Goscé, L. ve Anders, J. (2018). Analysing the link between public transport use and airborne transmission: Mobility and contagion in the London underground. Environmental Health, 17(84).

Hopkins, D.R. (1983). Princes and peasants: Smallpox in history. Chicago, IL: University of Chicago Press.

Horna-Campos, O.J., Consiglio, E., Sánchez-Pérez, H.J., Navarro, A., Caylà, J.A. ve Martín-Mateo, M. (2010). Pulmonary tuberculosis infection among workers in the informal public transport sector in Lima, Peru. Occupational and Environmental Medicine, 68(2), 163-165. 
Horna-Campos, O.J., Sánchez-Pérez, H.J., Sánchez, I., Bedoya, A., Martín-Mateo, M. (2007). Public transportation and pulmonary tuberculosis, Lima, Peru. Emerging Infectious Diseases, 13(10), 1491-1493.

Joseph, C.A., Ricketts, K.D., Yadav, R. ve Patel, S. (2009). Travel-associated Legionnaires' disease in Europe in 2009. Eurosurveillance, 15(41).

Kowalski, W.J. (2012). Hospital airborne infection control. Florida, FL: CRC Press.

Lederberg, J., Shope, R.E. ve Oaks, S.C. (Der.). (1992). Emerging infections: Microbial threats to health in the United States. Washington, D.C.: National Academy Press.

Mangili, A. ve Gendreau, M.A. (2005). Transmission of infectious diseases during commercial air travel. Lancet, 365(9463), 989-996.

McNeill, W.H. (1976). Plagues and people. Garden City, N.Y.: Anchor Press/Doubleday.

Mohr, O., Askar, M., Schink, S., Eckmanns, T., Krause, G. ve Poggensee, G. (2012). Evidence for airborne infectious disease transmission in public ground transport-A literature review. Eurosurveillance, 17(35).

Mokhtarian, P.L. ve Salomon, I. (1999). Traveling for the fun of it. ACCESS Magazine, 1(15).

Nasir, Z.A., Campos, L.C., Christie, N. ve Colbeck, I. (2016). Airborne biological hazards and urban transport infrastructure: Current challenges and future directions. Environmental Science and Pollution Research, 23(15), 15757-15766.

National Academies of Sciences, Engineering and Medicine (2013). ACRP Report 91: Infectious disease mitigation in airports and on aircraft. Washington D.C.: The National Academies Press.

Omrani, A.S., Al-Tawfiq, J.A., Memish, Z.A. (2015). Middle East Respiratory Syndrome Coronavirus (MERS-CoV): Animal to human interaction. Pathogens and Global Health. 109(8), 354-362.

Pan, X., Ojcius, D.M., Gao, T., Li, Z., Pan, C. ve Pand, P. (2020). Lessons learned from the 2019-nCoV epidemic on prevention of future infectious diseases. Microbes Infect, 22(2), 86-91.

Pappalardo, L., Simini, F., Rinzivillo, S., Pedreschi, D., Giannotti, F. ve Barabási, A. (2015). Returners and explorers dichotomy in human mobility. Nature Communications, 6(8166).

Shapiro, R., Hassett, K. ve Arnold, F. (2002). Conserving energy and preserving the environment: The role of public transportation (Report for the American Public Transportation Association). Erişim adresi: http://www.sonecon.com/docs/studies/enenv_0702.pdf

Shoghri, A., Liebig, J., Gardner, L., Jurdak, R. ve Kanhere, S. (2019). How mobility patterns drive disease spread: A case study using public transit passenger card travel data. Proceedings - 20th IEEE International Symposium, WoWMoM 2019. 
Shoghri, A., Liebig, J., Jurdak, R., Gardner, L. ve Kanhere, S. (2020). Identifying highly influential travellers for spreading disease on a public transport system. Proceedings - 21st IEEE International Symposium, WoWMoM 2020.

Siegel, J.D., Rhinehart, E., Jackson, M., Chiarello, L. ve the Healthcare Infection Control Practices Advisory Committee (2007). Guideline for isolation precautions: Preventing transmission of infectious agents in healthcare settings. Erişim adresi: https://www.cdc.gov/niosh/docket/archive/pdfs/NIOSH-219/0219010107-siegel.pdf

Sustainable Bus (2020). Bus disinfection through UV lights. A way to fight Coronavirus in Shanghai. Erişim adresi: https://www.sustainable-bus.com/news/bus-disinfection-through-uv-lights-a-way-to-fight-coronavirus-in-shanghai/

Şenbil, M. ve Yetişkul, E. (2020). Türkiye'de son dönem otomobilleşme: 2007-2018 arası iller bazında analizler. İdealkent Kent Araştırmaları Dergisi, 29(11), 372404.

Troko, J., Myles, P., Gibson, J., Hashim, A., Enstone, J., Kingdon, S., ... Van-Tam, J.N. (2011). Is public transport a risk factor for acute respiratory infection? BMC Infectious Diseases, 11(16).

Tsang, K.W, Ho, P.L., Ooi G.C, Yee, W.K., Wang, T., Chan-Yeung, M., ...Lai, KN. (2003). A cluster of cases of severe acute respiratory syndrome in Hong Kong. The New England Journal of Medicine, 348(20), 1977-1985.

UITP (2020). Public transport is Covid Safe. Policy Brief. Erişim adresi: https://cms.uitp.org/wp/wp-content/uploads/2020/10/Policy-Brief-PTisCOVID-Safe.pdf

Ward, K.A., Armstrong, P., McAnulty, J.M., Iwasenko, J.M. ve Dwyer, D.E. (2010). Outbreaks of pandemic (H1N1) 2009 and seasonal influenza A (H3N2) on cruise ship. Emerging Infectious Diseases, 16(11), 1731-1737.

WEF (2021). Here's how to build better public transport after Covid-19. Erişim adresi: https://www.weforum.org/agenda/2021/04/how-improve-public-transport-after-covid-19/

WHO (2003). Cumulative number of reported probable cases of SARS. Erişim adresi: https://www.who.int/csr/sars/country/2003_06_30/en/

WHO (2019). MERS situation update, November 2019. Erişim adresi: http://www.emro.who.int/pandemic-epidemic-diseases/mers-cov/mers-situation-update-november-2019.html

WHO (2021). Timeline: WHO's COVID-19 Response. Erişim adresi: https://www.who.int/emergencies/diseases/novel-coronavirus-2019/interactive-timeline\#!

Wilson, M.E. (1995). Travel and the emergence of infectious diseases. Emerging Infectious Diseases, 1(2), 39-46.

Wilson, M.E., Levins, R. ve Spielman A. (1994). Disease in evolution: Global changes and emergence of infectious diseases. New York, NYC: New York Academy of Sciences. 
Worldometer (2021). Covid-19 Coronavirus Pandemic. Erişim adresi (25 Eylül 2021): https://www.worldometers.info/coronavirus/

Yetişkul, E. (2017). Karmaşık Kentler ve Planlamada Karmaşıklık. Planlama, 27(1), 7-15.

Zhao, B., Ni, S., Yong, N., Ma, X., Shen, S. ve Ji, X. (2015). A preliminary study on spatial spread risk of epidemics by analyzing the urban subway mobility data. Journal of Biosciences and Medicines, 3(9), 15-21. 